\title{
Imagens do demônio nas missões jesuíticas da Amazônia espanhola
}

\section{Images of the Devil in the Jesuit Missions of the Spanish Amazon}

Francismar Alex lopes de Carvalho

Pós-doutorando

Universidade de São Paulo

Rua Rego Freitas, 527, ap.64, São Paulo, SP, 01220-010, Brasil

francismardecarvalho@gmail.com

RESUMo Este artigo analisa as representações do demônio nos textos dos missionários que atuaram na Amazônia espanhola, entre os séculos XVII e XVIII. Os missionários europeus, e em especial os jesuítas, inseriam o processo de "conquista espiritual" das terras amazônicas em uma narrativa de luta entre as forças do bem e do mal. Apresentavam-se como aqueles que vieram libertar os índios que viviam acorrentados à adoração do demônio, que se servia dos xamãs para promover toda a sorte de conflitos e danos, e inspirava celebrações e sacramentos que imitavam os da religião cristã, mas que ao fim e ao cabo apenas reforçavam a submissão dos nativos aos desígnios do comum inimigo. Este texto analisa em detalhe os diversos elementos constitutivos dessa narrativa. Ao contrário do que afirmam alguns estudos, a demonização não era tão somente uma forma de desqualificação das culturas indígenas. Os jesuítas enquadravam como demoníacas aquelas práticas que tentavam conhecer e cujo sentido mais imediato lhes escapava. A imagem do

Recebido: 03 de julho de 2015 | Aprovado: 20 de agosto de 2015

http://dx.doi.org/10.1590/0104-87752015000300005

Varia Historia, Belo Horizonte, vol. 31, n. 57, p. 741-785, set/dez 2015 
demônio servia, portanto, para traduzir uma cultura em outra, tornar a cultura nativa inteligível. A demonização não significava o rechaço absoluto ao Outro, antes era uma tentativa de estabelecer pontes analógicas por meio das quais o diálogo intercultural e a negociação do universo do sagrado podiam fluir.

Palavras-Chave missões jesuíticas, Maynas, demonologia

Abstract This paper analyzes the representations of the devil in the texts of the missionaries who worked in the Spanish Amazon, between the seventeenth and eighteenth centuries. European missionaries, especially the Jesuits, understood the process of "spiritual conquest" of the Amazonian region as a narrative of struggle between the forces of good and evil. They presented themselves as those who came to free the Indians who were under the devil's domination. Fathers conceived that Satan was using shamans to promote all kinds of conflicts and damage, and to inspire celebrations and sacraments that mimicked those of the Christian religion, but at the end only reinforced the submission of the natives to the common enemy's designs. This paper analyzes in detail the various constituent elements of the narrative. This paper analyzes in detail the various constituent elements of the narrative. Contrary to what some studies suggest, the demonization was not just a form of disqualification of indigenous cultures. Jesuits called "diabolical" customs and rituals that they tried to know and whose meaning escaped them. The image of the demon was used, therefore, to translate one culture into another, to make intelligible a native culture. Demonization was not the absolute rejection of the Other. Demonization was an attempt to build bridges and analogies through which intercultural dialogue and the negotiation of the sacred could flow.

KEYWORDS Jesuit missions, Maynas, demonology 
If no devils, no God.

The Triall of Maist. Dorrell (1599) apud Thomas (1997, p.469).

\section{INTRODUÇÃO: O DEMÔNIO NO NOVO MUNDO}

A assimilação das deidades indígenas ao diabo cristão fundou-se na convicção, compartida por não poucos religiosos europeus, de que depois de cristianizada a Europa, o demônio e sua horda infernal haviam-se retirado para a América. ${ }^{1}$ Segundo o sentir comum, o diabo erigira no Novo Mundo um verdadeiro império, que aprisionava os índios em práticas e rituais idolátricos. Nessa perspectiva, a idolatria, ou seja, a adoração de falsos deuses, na América, equivalia quase sempre à demonolatria, ou seja, à adoração do diabo (Ragon, 1988, p.164-166). Semelhante concepção justificava uma ideologia da conquista como luta contra o demônio e seu séquito infernal, com a finalidade de salvar as almas dos índios, as quais, se seguissem nas garras do comum inimigo, estavam infalivelmente destinadas a padecer eternamente no inferno (Gareis, 2008, p.53). A América foi percebida - como sugere a obra do P. José de Acosta, que ali esteve de 1571 a 1587 - como o reino absoluto de Satã, desprovida que estava das muralhas espirituais da Igreja. Como escreve o jesuíta: "ya que la idolatría fué extirpada de la mejor y más noble parte del mundo, retiróse a lo más apartado: y reinó en estotra". ${ }^{2}$ Os europeus percebiam-se diante de um continente em que o demônio havia tido tempo de "fortificar-se" (Cañizares-Esguerra,

1 Siglas e abreviaturas dos arquivos consultados: AGI: Archivo General de Indias, Sevilla; AHN: Archivo Histórico Nacional, Madrid; ARSI: Archivum Romanum Societatis Iesu, Roma; NR et Q: Fundo Nuevo Reino e Quito; BNM: Biblioteca Nacional de España, Madrid; BNVE: Biblioteca Nacional Vitorio Emanuele II, Roma; Comillas/CP: Universidad Pontificia Comillas, Biblioteca de la Sede Cantoblanco, Colección Pastells, Serie Negra, Madrid; NYPL: The New York Public Library, New York.

2 ACOSTA, José de, S.J. Historia natural y moral de las Indias [1590]. Madrid: CSIC, 2008, liv. 5, cap. 1, p.154. 
2008, p.35). Como lembra Rozat Dupeyron (1995, p.88), onipresente em todo o continente americano, o diabo tinha todas as características e faculdades do demônio clássico: podia falar, aparecer e desaparecer ao seu antojo, metamorfosear-se, imiscuir-se no sonho dos índios, possuir as almas e os corpos dos espanhóis, índios e negros, fazer pactos com os bruxos etc.

A compreensão coeva era a de que, sem a presença do demônio, não havia Igreja e nem mesmo império (Rozat Dupeyron, 1995, p.85). Daí a obsessão dos missionários da Nova Espanha, já nas primeiras décadas do século XVI, com a identificação do demônio cristão em práticas e crenças indígenas. Os Colloquios entre os primeiros franciscanos e as autoridades religiosas nativas, que tiveram lugar em 1524, já procuravam apresentar certas divindades pré-hispânicas como demônios. Frei Bernardino de Sahagún, cronista franciscano que preparou, com o auxílio de seus neófitos, uma transcrição dessas conversações em 1564, diz tratarem-se efetivamente dos sequazes do maligno. ${ }^{3}$ Do mesmo modo, inspirado na demonologia do franciscano basco Martín de Castañega, frei Andrés de Olmos publicava em 1553 seu Tratado de hechicerías $y$ sortilegios, escrito em náhuatl, em que apresentava uma descrição que não tinha tanto a ver com o mundo pré-hispânico, pois incluía em toda parte o demônio cristão (Baudot, 1996, p.238). Ao mencionar o homem coruja das antigas tradições mexica, diz tratar-se do próprio diabo: "vosotros habéis de saber que este hombre-búho se nombra, se

3 "Se transformaron entonces en demonios,/ En los que vosotros llamáis/ tzitzimime, culeletin,/ y a los que también llamáis vosotros/ Tzontémoc, 'el que cáe de cabeza’ Piyoche,/ Tzonpachpul, 'el de los pelos colgantes a modo de heno', Cuezal/ Muy tenebrosos, muy sucios,/ muy dignos de temerse" (SAHAGÚN, Bernardino de, O.F.M. Coloquios y doctrina cristiana [...]. Los diálogos de 1524, dispuestos por fray Bernardino de Sahagún y sus colaboradores [1564]. México: Univ. Nacional Autónoma de México, 1986 (ed. de Miguel León-Portilla), cap. 10, 1442-1449, p.173, p.175). Segundo as notas León-Portilla, as entidades referidas eram, para os astecas, seres noturnos e temíveis, e os tzitzimimeh, em particular, apareciam ao fim de cada era cósmica para devorar os humanos (In: Sahagún, 1986 [1564], n. 7-9, p.173); ver também: DUVERGER, 1993, p.78-79 e BAUDOT, 1996, p.234. 
llama verdaderamente por una multitud de nombres: mal ángel, Diablo, Demonio, Sathán".4

Os primeiros evangelizadores não deixaram de qualificar como paródias de Satã as honras que os ameríndios dirigiam às suas divindades, e que guardavam alguma semelhança com as cristãs (Ragon, 1988, p.171). Assim, frei Diego Durán, missionário dominicano, apresentará os sacrifícios como representações simbólicas dos deuses astecas em que o que estava sendo parodiado era o sacramento cristão da eucaristia. ${ }^{5}$ Após as reformas tridentinas, que acirraram a ortodoxia dos rituais e crenças, não poucas práticas e concepções ensinadas durante as primeiras décadas de evangelização foram classificadas, elas também, como paródias e imitações demoníacas. Assim, por exemplo, o uso do quipus - instrumento incaico que consistia em um conjunto de cordas e nós alternados e de distintas cores, que permitiam, mediante múltiplas combinações, diversos tipos de contabilização - nas confissões, antes estimulado, foi finalmente reprimido a partir de 1649 (Estenssoro Fuchs, 2003, p.223-239).

As práticas religiosas e rituais eram frequentemente separadas das crenças que as proviam de conteúdo conceitual, e as narrativas míticas e históricas que davam sentido aos rituais e crenças, e que conformavam uma unidade coerente, eram simplesmente ignoradas (MacCormack, 1991a, p.136). No Peru, menos do que descrever um sistema religioso, o jurista Polo de Ondegardo - em seu informe "Los errores y supersticiones de los indios", inserido na Doctrina christiana y catecismo do Terceiro Concílio Limenho, publicada naquela capital em 1585 -,

4 OLMOS, Andrés de, O.F.M. Tratado de hechicerías y sortilegios [1553]. México: Univ. Nacional Autónoma de México, 1990, cap. 1, p.12-13. Tratava-se de reduzir todas as entidades espirituais concebidas pelos indígenas a demônios, como se nota nos escritos de frei Sahagún: "otro diablo adoraron vuestros antepasados, el cual tenía bajo de su obediencia otros muchos demonios; llamáronle Texcatzóncatl; decían que era el dios del pulcre; hacíanle fiesta muchas veces cada año" (SAHAGÚN, Bernardino de, O.F.M. Historia general de las cosas de Nueva España [1585]. 3. ed. México: Editorial Porrúa, 1975, p.63).

5 DURÁN, Diego, O.P. Historia de las Indias de Nueva España e islas de la Tierra Firme [1581], 2 vols. México: Editorial Porrúa, 1967, p.181. 
recuperando a tradição erudita de descrições de bruxas, descrevia o que via ou ouvia falar por meio de analogias com as formas europeias de superstição (Silverblatt, 1982, p.40; 1990, p.120-127). "Sintiendose alguno enfermo luego acude a estos hechizeros, para que deshagan el daño que sospechan averse les hecho", escrevia Polo, que considerava ainda que "son estas hechizeras en gran manera temidas aun de los Caciques". Reminiscências de descrições eruditas da bruxaria europeia podiam ser, assim, recuperadas, de modo que Polo dizia existirem nos Andes bruxas que voavam pelos céus e falavam com o demônio. ${ }^{6}$

Que os religiosos exortassem os índios a ficarem longe dos çupay, definidos como demônios, ${ }^{7}$ era o que dispunha o Sermão VI, recomendado pelo Terceiro Concílio Limenho, e publicado em Lima, em 1585, na coleção de sermões do Tercero Cathecismo y Exposición de la Doctrina Christiana. Nesse sermonário, os demônios eram definidos como anjos maus que encorajavam os índios a adorar huacas, consultar feiticeiros, e cometer pecados que provocavam a reprovação de Deus: "Estos son los que llamamos Diablos, y Demonios, y çupay, que como

6 ONDEGARDO, Polo de. "Los errores y supersticiones de los Indios" [1585], cap. 10, §2, f. 12 (In: Doctrina christiana y catecismo para instrucción de Indios, 1985, vol. 2, p.275): “[...] toman la figura que quieren y van por el ayre en breve tiempo mucho camino: y ven lo que passa: hablan con el demonio: el qual les responde en ciertas piedras, o en otras cosas que ellos veneran mucho".

7 Nesse processo, houve um deslizamento na tradução da palavra indígena para demônio. No início do século XVII, missionários e extirpadores procuraram transformar no conceito cristão de demônio a noção ambivalente utilizada em décadas anteriores. Cieza de León, por exemplo, havia notado que os índios chamavam de Sopay ao espírito que entrava nos corpos dos mortos e animava-os a falar com os vivos; para o cronista espanhol, esse Sopay era o demônio (CIEZA DE LEÓN, Pedro de. Crónica del Perú: el señorío de los Incas [1553]. Caracas: Ayacucho, 2005, p.178). Domingo de Santo Tomás, em seu Lexicon o Vocabulario de la lengua general del Peru, de 1560, traduziu cupay por "ángel, bueno, o malo", "demonio, trasgo de casa", e em um sentido próximo ao paganismo antigo, “demonio bueno o malo”. Domingo de Santo Tomás conseguiu captar, portanto, o sentido andino segundo qual o cupay não era necessariamente mau. Essa ambivalência foi depurada pelos escritos de Acosta e do Terceiro Concílio Limenho de 15821583 (MACCORMACK, 1991a, p.254-255). Em De Procuranda, redigido entre 1576 e 1577, o P. Acosta afirmava que o zupai não era outro senão o inimigo de Deus. ACOSTA, José de, S.J. De procuranda indorum salute [1588]. Madrid: CSIC, 1984, 2 vols., vol. 1, liv. 1, cap. 15, p.207; vol. 2, liv. 5, cap. 10, p.269. 
son malos, y enemigos de Dios, aborrecen a los hombres q son ymagen, y hechura de Dios". A razão disso residia em que os demônios eram grandes invejosos, "porque los hombres van al cielo a gozar los bienes, que ellos perdieron: y por esso engañavan a los hombres y les persuaden que no adoren a Dios, ni crean en Iesu Christo, mas que adoren las guacas, donde ellos están, y quieren ser adorados de los hombres". "Estos malos Demonios son los que hablan a los hechizeros", e eram os que persuadiam a que a gente cometesse adultérios, homicídios, furtos e todos os pecados. ${ }^{8}$

As idolatrias praticadas pelos índios, como concebidas pelo P. Acosta, não eram uma forma errônea de religião natural (segundo pensava frei Bartolomé de Las Casas, o desejo natural, não necessariamente demoníaco, de conhecer Deus), mas a expressão da influência direta do demônio, "que siempre apetece y procura ser tenido y honrado por Dios" (Acosta, 2008 [1590], liv. 5, cap. 1, p.153; cf. Duviols, 1977, p.17-20, p.24-53). Para o jesuíta, toda a religião indígena era idolatria, e a idolatria era obra do demonio: "de donde se ve la malicia y tiranía del demonio que en esto ha querido exceder a Dios, gustando ser adorado con derramamiento de sangre humana, y por este camino procurando la perdición de los hombres en almas y cuerpos, por el rabioso odio que les tiene como su tan cruel adversario" (Acosta, 2008 [1590], liv. 5, cap. 19, p.177). Contudo, o P. Acosta (2008 [1590], liv. 5, cap. 31, p.198; liv. 6, cap. 28, p.227) não condenava inteiramente todos os costumes indígenas. A tarefa do missionário consistia em identificar precisamente o que era costume não associado à religião e o que era religião propriamente, esta sim alvo de extirpação (cf. Green Jr., 2011, p.173).

Coerente com a tendência da época de organizar o discurso em termos de oposições e inversões, ${ }^{9}$ também o P. Acosta (2008 [1590], liv. 5,

8 "Sermon VI. En que se enseña como Dios crio a los angeles, y como ay Angeles buenos, que nos ayudan, y malos, que nos engañan", Tercero Cathecismo y Exposición de la Doctrina Christiana, por Sermones (Lima, 1585), f. 33v-38, cit. f. 34v-35 (In: Doctrina christiana y catecismo para instrucción de Indios, 1985, vol. 2, p.416-417).

9 A partir de meados do século XVI, os escritos sobre bruxaria e demônios geralmente estruturavam-se em oposições e inversões, que enfatizavam o contraponto moral entre vícios 
cap. 11, p.167) argumentava que as analogias entre ritos e crenças andinas e o cristianismo não passavam de imitações emuladas pelo demônio: "Y así vemos que - como el Sumo Dios tiene sacrificios y sacerdotes y sacramentos, y religiosos y profetas y gente dedicada a su divino culto y ceremonias santas - así también el demonio tiene sus sacrificios y sacerdotes y su modo de sacramentos, y gente dedicada a recogimiento y santimonia fingida, y mil géneros de profetas falsos". Escrevendo em um contexto pós-tridentino, o P. Acosta assumia o entendimento de que a certeza teológica não admitia desvios (MacCormack, 1991b, p.269). Cerimônias indígenas que tinham alguma similitude com as cristãs não podiam ser vistas como um preparativo providencial (como sugeria frei Motolinía), mas tão somente como emulações do diabo. Esse "desejo mimético" de imitação do culto divino pelo demônio não podia ser mais evidente em suas tentativas de imitar os sacramentos cristãos, pois havia instituído falsas versões do batismo, do matrimônio, da confissão e da unção sacerdotal; no México, a eucaristia estava unida a um banquete comunal e à ingestão de um pequeno ídolo, fabricado com pasta de milho e mel (Acosta, 2008 [1590], liv. 5, cap. 24, p.184; cf. Cervantes, 1996, p.50-52).

A América estava, portanto, sob a tirania de Satanás. ${ }^{10}$ Diego de Valadés, franciscano mestiço mexicano nascido em 1533, publicou em sua

e virtudes. Em estudo atento aos aspectos discursivos, CLARK, 1997, p.80-90, mostra que, nesses textos, demônios e bruxas invertiam o mundo de diversas formas, dada a capacidade do demônio de parodiar a doutrina cristã e dissimular o fato de que os ritos e celebrações acabavam por dirigir-se a si mesmo. O demônio era, portanto, o símio de Deus. Frei Martin de Castañega, por exemplo, em seu Tratado de las supersticiones y hechicerías, publicado em Logroño, em 1529, afirmava que, do mesmo modo que a Igreja Católica contava com seus sacramentos, a igreja do diabo tinha suas execramentos (imitações dos sacramentos).

10 Era impossível que os missionários ignorassem a problemática da demonização, dada a proliferação bibliográfica sobre o tema na Europa ocidental. MANDROU, em Magistrats et sorciers, 1980, p.24 s.s, catalogou, para o caso francês, ao redor de 340 obras de demonologia editadas entre os séculos XVI e XVII, as quais deram origem a cerca de 340 mil exemplares desse tipo de literatura. No mundo de fala alemã, na segunda metade do século XVI, circulavam 231.600 exemplares de livros que tratavam de temas demoníacos. O Malleus Malificarum teve, entre 1486 e 1669, 34 edições, o que significa entre 30 e 50 mil exemplares. A obra De la Demonomanie des Sorciers, de 1580, escrita por Jean Bodin, foi editada 20 vezes em 20 anos. 
Rhetorica christiana, de 1579, uma imagem em que os índios apareciam como escravos do demônio, atados por grilhões. ${ }^{11}$ Para os missionários, a sua presença em Indias era vista como parte de uma guerra santa espiritual, o último ato da luta milenária entre as forças do bem e do mal (Phelan, 1972, p.24-25).

Esse discurso era recorrente nos escritos dos jesuítas que atuaram na Amazônia espanhola. "El diablo los lleva tan atados a sí que casi no hay medios de arrancarlos", escrevia o P. Zephyris. ${ }^{12}$ Os jesuítas estavam, portanto, "arrancando de las garras del demonio" as almas que mantinha presas. ${ }^{13}$ Que se tratasse de uma verdadeira "esclavitud del Demonio", os padres não tinham dúvidas a respeito. ${ }^{14} \mathrm{Em}$ toda a Amazônia, afirmava alguém, havia "docientas mil almas que tiraniza el Demonio". ${ }^{15}$ Tirania que se manifestava nos danos físicos sofridos pelos índios: os Yurimaguas diziam que o demônio tinha o costume de "azotarlos cruelmente"16 e os Chamicuros sofriam "visibles malos tratos de los demonios". ${ }^{17}$

Numerosas referências nos textos de missionários atestavam que, segundo sua compreensão, o demônio era responsável por instigar ações e influir em vários aspectos da vida dos índios amazônicos. Um

O tema exercia tal fascinação que houve quem intentasse calcular o número de demônios existentes: para Jean Wier, eram 7.409.127, conduzidos por 72 generais de Satanás (ROZAT DUPEYRON, 1995, p.82-84; DELUMEAU, 2012, p.171).

11 CAÑIZARES-ESGUERRA, 2008, p.123-125. Do mesmo modo, o puritano Cotton Mather (1663-1728), em Batteries upon the Kingdom of the Devil, de 1695, afirmava que o diabo era "señor absoluto" entre os índios, pois "se adentra en todas las facultades del alma, el intelecto, la memoria y los afectos” (apud CAÑIZARES-ESGUERRA, 2008, p.125).

12 Francisco Javier Zephyris a Francisco Javier Goettner, Andoas, 10 jul. 1727, MATTHEI, 1972, p.207.

13 AGI, Charcas, 384, Miguel Bernardino de la Fuente y Rojas, bispo de Santa Cruz de la Sierra, ao rei, Mizque, 29 mar. 1735, f. 2.

14 AGI, Lima, 407, “Breve noticia”, Pedro Marbán, 1700, f. 6, 8.

15 AGI, Quito, 143, n. 20, "Memorial de Juan Bautista Sánchez de Orellana, oidor que fué de la Audiencia de Quito", Quito, 29 fev. 1720, f. 291v.

16 MARONI, Pablo, S.J. Noticias auténticas del famoso río Marañón y misión apostólica de la Compañía de Jesús [1738]. Iquitos, Perú: CETA, 1988, p.172.

17 Comillas/CP, Serie Negra, Cuaderno n. 108, f. 75-105, "Aditamento a los Apuntes", Adan Widman, c. 1762, f. 103. 
intérprete, "instigado del enemigo común", suicidava-se, e o "Demonio, para impedir los frutos que tantos le lastimaban", concitara um conflito entre os soldados espanhóis e os caciques, que pôs a perder um promissor descimento de índios. ${ }^{18}$ Para dissolver a boa correspondência entre o padre e seus neófitos, o demônio - por meio dos feiticeiros - convencia de que o sinal da cruz e o livro de batismos serviam para distribuir a comunidade em encomiendas aos espanhóis. ${ }^{19}$

Para colonos e religiosos, a colonização era uma batalha real dirigida à expulsão dos demônios da terra. Demônios que eram entendidos como entes reais, com forças físicas que influíam no cotidiano, e não como metáforas (Cañizares-Esguerra, 2008, p.30). As origens da noção de que o demônio era uma realidade física remontam ao Novo Testamento, em que o demônio aparecia como personificação do mal; Orígenes de Alexandria foi dos primeiros a privar Satanás de sua origem divina como anjo caído; as hagiografias dos monges do deserto dotaram o demônio de personificações; contudo, prevaleceu a ideia de que o demônio não podia obrigar alguém a pecar contra a sua vontade. ${ }^{20}$

Este artigo analisa as representações do demônio nos textos dos missionários que atuaram na Amazônia espanhola, entre os séculos XVII e XVIII. Os padres jesuítas Lucas de la Cueva e Gaspar Cujía chegaram a Borja, cidade mais oriental na jurisdição da Audiência de Quito, em fevereiro de 1638. Ao prosseguir o trabalho missionário entre os índios amazônicos, em ocasião de haver desamparado essa cidade os clérigos e outros religiosos mercedários e agostinhos, que se retiraram após uma revolta dos Maynas contra seus encomenderos,${ }^{21}$ principiavam a

18 AGI, Quito, 134, n. 10, "Informe del P. Provincial de San Francisco de Quito, sobre las misiones de su religión”, Bartolomé de Alcano, post. a 18 jul. 1739, f. 2v.

19 MERCADO, Pedro de, S.J. Historia de la Provincia del Nuevo Reino y Quito de la Compañía de Jesús [1684], 4 vols. Bogotá: Biblioteca de la Presidencia de Colombia, 1957, vol. 4, p.165.

20 CERVANTES, 1996, p.35. As recorrentes afirmações dos missionários de que o demônio estava fisicamente presente entre os índios estavam amparadas na crença, amplamente difundida entre os europeus educados, segundo a qual, se os demônios podiam interferir na matéria, era porque eram parte do (e limitados pelo) mundo natural (CLARK, 1997, p.162).

21 ARSI, NR et Q, 15, i, “Información jurídica a instancia del P. Lorenzo Lucero”, 1684, f. 105. 
formação de uma das mais importantes missões que os jesuítas constituíram na América do Sul. De 1638 a 1660, os jesuítas realizaram intensas explorações no vale do rio Marañón e reduziram os grupos Maynas, Jeberos e Cocamas. Entre 1660 e 1700, a missão se expandiu às margens dos rios Guraray, Tigre e afluentes meridionais do Marañón. Finalmente, entre 1720 e 1767, fundaram a chamada "missão baixa", entre as sociedades Tupi dos rios Napo e médio Amazonas. ${ }^{22}$ Não é certo, entretanto, que as missões de Maynas resultaram em um completo fracasso: o número de índios reduzidos passou de 7.966 almas em 28 pueblos, em 1719, às 11.281 almas, em 21 pueblos, em 1768. ${ }^{23}$

Os missionários europeus, e em especial os jesuítas, inseriam o processo de "conquista espiritual" das terras amazônicas em uma narrativa de luta entre as forças do bem e do mal. Apresentavam-se como aqueles que vieram libertar os índios que viviam acorrentados à adoração do demônio, que se servia dos xamãs para promover toda a sorte de conflitos e danos, e inspirava celebrações e sacramentos que imitavam os da religião cristã, mas que ao fim e ao cabo apenas reforçavam a submissão dos nativos aos desígnios do comum inimigo. Este texto analisa em detalhe os diversos elementos constitutivos dessa narrativa. Ao contrário do que afirmam alguns estudos, a demonização não era tão somente

Cf. AGI, Quito, 11, r. 3, n. 37, "Relación de Pedro Vaca de la Cadena”, 1629; JOUANEN, 1941, vol. 1, p.328 e BAYLE, 1949, p.12-13.

22 GROHS, 1974, p.124. Dificuldades específicas experimentaram os padres da Companhia, entre as quais a impressionante diversidade linguística e cultural; o aguerrido faccionalismo, que obrigava à fundação de numerosas reduções; a falta de missionários; e a influência de escravistas portugueses. Sobre esses temas, ver: GOLOB, 1982, p.151, p.161-164 e STEPHAN, 2000, p.91-94. Os missionários reconheciam que a falta de produtos de alto valor comercial, de cuja exportação pudessem sacar recursos para manter mais religiosos e ofertar ferramentas, roupas e avelórios a contento dos índios, foi um fator decisivo que impediu que as missões avançassem como esperado (ARSI, NR et Q, 15, i, f. 114-114v, Enrique Richter a José Antonio de la Rentería, La Laguna, 19 set. 1686; AGI, Quito, 4, "Copia de carta del Padre Samuel Fritz", Pará, 1691, f. 328; "Wenceslao Breyer a su hermano", Santiago de la Laguna, 18 jun. 1699, MATTHEI, 1969, p.254). Sobre a falta de recursos, ver também REEVE, 1993, p.127-134.

23 BNVE, Ms. Gesuitico 1249/1 (3378), all. I, “Catalogus Missionum Gentilium Societatis Jesu in Provincia Quitensi. Missiones Maynarum fluvii Marañon et Amazonas”, 1719; BNM, Mss/17614, "Censo de las misiones de Maynas", Archidona, 15 fev. 1768, f. 35 [f. 75]-41 [81]. 
uma forma de desqualificação das culturas indígenas. Os jesuítas enquadravam como demoníacas aquelas práticas que tentavam conhecer e cujo sentido mais imediato lhes escapava. A imagem do demônio servia, portanto, para traduzir uma cultura em outra, tornar a cultura nativa inteligível. A demonização não significava o rechaço absoluto ao Outro, antes era uma tentativa de estabelecer pontes analógicas por meio das quais o diálogo intercultural e a negociação do universo do sagrado podiam fluir.

\section{O DEMônio na Amazônia}

É nesse quadro geral de demonização das culturas indígenas que os jesuítas escreveram sobre as populações com quem mantiveram contato nas terras baixas da Amazônia. Uma opinião corrente entre os missionários dessas regiões era a de que os índios encontravam-se desprovidos de qualquer conhecimento de Deus, ao passo que o diabo, esse sim o conheciam e temiam. "Lo general entre ellos es", escrevia o P. Magnin, ${ }^{24}$ "no conocer a Dios, ni temerlo ni adorarlo"; em compensação, "al Diablo todos los conocen, y lo temen”. Mas o P. Veigl parecia reconhecer, já tardiamente, que alguns consideravam o príncipe das trevas em alta estima: "lo temen por instinto servil como algo que al ser ofendido puede causar toda clase de daño; y también lo aman como protector magnánimo de infortunios" ${ }^{25}$

24 MAGNIN, Juan, S.J. Descripción de la Provincia y misiones de Mainas en el Reino de Quito [1740]. Quito: Biblioteca Ecuatoriana “Aurelio Espinosa Pólit”: Sociedad Ecuatoriana de Investigaciones Históricas y Geográficas, 1998, p.475.

25 VEIGL, Francisco Xavier, S.J. Noticias detalladas sobre el estado de la provincia de Maynas en América meridional hasta el año 1786. Iquitos: CETA, 2006, p.230-231. As opiniões sobre o conhecimento que cada grupo possuía a respeito do Criador variavam consideravelmente. Se o P. Magnin não reconhecia qualquer conhecimento prévio de Deus entre os índios de Maynas, não podia encontrar apoio para o seu argumento no informe do P. Figueroa, que escrevera no século anterior: "Todas las naciones que hasta aora se han tratado tienen conocimiento de Dios y vocablo con que en cada idioma lo nombran, llamándolo también Nuestro Padre y Nuestro Abuelo"; não bastasse isso, "dicen que crió el cielo, la tierra, hombres y demás cosas, y que criando las comidas para su hijos, que son los hombres, se fue al cielo". Atestar que os índios reconheciam um Deus criador não impedia o P. Figueroa de reproduzir a perspectiva 
Os índios incorporaram o demônio cristão como uma divindade a mais em seu panteão. Dada a insistência dos primeiros missionários em ver o demônio na maioria dos rituais e crenças indígenas, estes se apropriaram do inimigo comum como uma divindade adicional, ou simplesmente passaram a chamar de diabo certos espíritos malignos já conhecidos. Um diabo corpóreo, material, com fisionomia própria, jovem, velho, em forma de papagaio e de outros animais, e perfeitamente capaz de estabelecer o pacto demoníaco, com seus juramentos feudais de lealdade e vassalagem. Os padres operaram, assim, uma metamorfose das entidades que, sem ser inteiramente más, causavam danos, na figura cristã do diabo. Na Nova Espanha, já em princípios do século XVII, o diabo parecia estar incorporado com êxito aos esquemas de pensamento nativos (Cervantes, 1993, p.182-185; 1996, p.82; Bernabéu Albert, 2000, p.148). Nesse ponto, parece que os índios seguiram o missionário sem muita dificuldade: "le atribuyen sus enfermedades", diz o P. Gumilla, ${ }^{26}$ referindo-se aos sentimentos dos naturais em relação ao demônio: "le atribuyen la muerte de todos los párvulos [...] les rompe el pescuezo con gran secreto". É assim que um índio, tendo ouvido um sermão detalhado sobre o diabo, exclamou: "Ese perro es sin duda el que anda paseándose por el monte" (Maroni, 1988 [1738], p.378). Observava o mesmo padre que "en hablándoles de ese espíritu infernal y suplicios con que atormenta a los malos en el Inferno, se ponen muy atentos a escucharme". ${ }^{27}$

Se os índios aceitaram bem a ideia de demônio, o mesmo não se pode dizer da ideia de inferno. Os informes dos missionários dão conta de que os nativos continuavam a rechaçá-la. Como dar crédito à

pós-tridentina de que a religiosidade ameríndia não possuía qualquer institucionalidade, com o que justificava a presença dos missionários: "no le dan culto ninguno, como debieran, en reconocimiento de que es Criador, ni le invocan para cosa, ni para jurar, ni saben qué cosa es juramento". (FIGUEROA, Francisco de, S.J. Relación de las misiones de la Compañía de Jesús en el país de los Maynas [1661]. Madrid: Victoriano Suárez, 1904, p.234-235; Cf. MERCADO, 1957 [1684], t. 4, p.239, p.249).

26 GUMILLA, Joseph, S.J. El Orinoco ilustrado: historia natural, civil y geográfica de este gran río [1741]. Bogotá: Editorial ABC, 1955, p.246.

27 Pablo Maroni a Angel Maria Manca, La Laguna, 21 dez. 1731 (In: MARONI, 1988 [1738], p.378). 
existência do inferno, um lugar onde seus antepassados, que não haviam conhecido o cristianismo, padeceriam eternamente, juntamente como os mais prestigiosos guerreiros e xamãs? A partir dos informes que o $\mathrm{P}$. Mercado (1957 [1684], vol. 4, p.244) pôde reunir até 1684, tudo parece indicar que não poucos índios mantinham algumas das suas antigas concepções e procuravam conciliá-las com os ensinamentos cristãos que recebiam. Em geral, esperavam ver no céu seus parentes mortos, que os estariam esperando com mandioca e banana maduros. Ao que os padres contrapunham que seus ancestrais não estavam no céu, por terem morrido como gentis, e que os gozos eternos não eram materiais, mas espirituais, pois consistiam em contemplar a Deus. ${ }^{28}$

Assim, parece que os índios aceitaram com mais facilidade a ideia de que havia um demônio, mas o conceito de inferno pareceu-lhes absurdo. Como prossegue o P. Magnin (1998 [1740], p.205): "no les cuesta creer lo que se les dice de Dios y del paraíso, pero lo que es del infierno, no pueden aceptar que exista. 'Mientes - dicen algunas veces, en la cara del misionero -, no hay infierno". Em outro passo, o mesmo jesuíta sublinhou o espírito de dúvida que pairava sobre os índios: "Del demonio, q.' lo ay, si; q' es malo; q.' hace graves daños; pero q.' ayga infierno, y q.' ay esta penando con los condenados, esso no lo entienden; alla estará en la montaña, muestran con las manos: quien sabe, donde?". ${ }^{29}$ Sobre a

28 Tema espinhoso era o das penas e castigos que corresponderiam a cada um no além. Alguns acreditavam que as almas das pessoas que cometeram maldades ficavam penando na terra, razão pela qual colocavam nas portas de suas casas algumas imundícies, na crença de que com elas impediam e afugentavam semelhante companhia. Outros não reconheciam como maus seus pecados, e rejeitavam que pudessem ser castigados eternamente por eles (MERCADO, 1957 [1684], t. 4, p.247-248). Do mesmo modo, como verificou o P. Magnin (1998 [1740], p.215), entre os Omagua estava difundida a crença de que o destino mais privilegiado para a vida após a morte, um sítio localizado acima do sol, estava reservado a todos os daquela nação, qualquer que fosse sua vida; “allí también están los brujos más famosos" e também os esperavam seus antepassados.

29 AHN, Jesuitas, leg. 251, 10, "Descubrimiento del Nucuray junto a Pastaza en la prov.a de Maynas", Juan Magnin, Borja, 1742, f. 4. Os jesuítas tiveram que se deparar, portanto, com apropriações originais e imprevistas da doutrina cristã. Daí a necessidade de lembrar continuamente os nativos da importância do inferno. Em um texto intitulado "Modo de confesar los Ticunas nuevos", a primeira pergunta era a seguinte: “ ¿Has dicho: no hay Dios, no hay infierno, 
imortalidade da alma, os índios das margens do rio Nucuray, junto ao Pastaza, visitados pelo P. Magnin em 1742, afirmavam “q.' al morir sus almas, las unas entran en el cuerpo de tigres, venados, y otros animales; las otras se van alla arriba en el cielo, para estar con sus parientes". ${ }^{30}$

Embora alguns missionários assinalassem que os índios conheciam o demônio e não lhe dirigiam culto algum, outros preferiram considerar como dirigidos ao diabo certos ritos e oferendas. Segundo apurou o procurador P. Manuel Rodríguez, ${ }^{31}$ para "hablar con el demonio", os xamãs guardavam como relíquias ossos de feiticeiros mortos. ${ }^{32} \mathrm{O}$ procurador Frei Manuel Cisneros, escrevendo em 1712, em nome dos franciscanos que atuavam na Amazônia, diz que os índios faziam "ofrendas al demonio de varias figuras de primales y sebandijas". ${ }^{33}$ Se os jesuítas podiam aproveitar a experiência dos índios com certo espíritos que podiam causar males, de modo a convertê-los no diabo, este podia ser aceito como mais uma entidade no panteão nativo (e mesmo como uma espécie de santo), sem ser necessariamente bom ou mau o tempo todo (Cervantes, 1993, p.182). Chama a atenção, portanto, que os jesuítas

no van allá los malos? O que yanga dicen los Padres esas cosas (sin fundamento)" (URIARTE, Manuel Joaquín, S.J. Diario de un misionero de Maynas [1775]. Iquitos: Monumenta Amazónica, 1986, p.619). Do mesmo modo, o P. Ruiz de Montoya, quando procurou explicar aos Guarani em detalhe o tema do inferno, foi chamado de mentiroso e ameaçado pelos ouvintes com as armas nas mãos. RUIZ DE MONTOYA, Antonio. Conquista espiritual hecha por los religiosos de la Compañia de Jesús en las provincias del Paraguay, Paraná, Uruguay y Tape [1639]. Bilbao: Imprenta del Corazón de Jesús, 1892, cap. 30, p.124.Também o P. José Cardiel estranhava a tranquilidade com que os índios ouviam, durante a confissão, a ameaça de que podiam ir para o inferno (Carta a Pedro de Calatayud, Buenos Aires, 20 dez. 1747 apud MARTINI, 1990, p.355-356).

30 AHN, Jesuitas, leg. 251, 10, "Descubrimiento del Nucuray junto a Pastaza en la prov.a de Maynas", Juan Magnin, Borja, 1742, f. 4.

31 RODRÍGUEZ, Manuel, S.J. El Marañon, y Amazonas [...]. Madrid: En la imprenta de Antonio Gonçalez de Reyes, 1684, p.117-118.

32 O mesmo passava entre os Guarani, como escreve o P. Ruiz de Montoya (1892 [1639], cap. 29, p.121), que qualifica esse rito de "creencia vana y idolatría"; cf. também as observações do P. del Techo (TECHO, Nicolás del, S.J. Historia de la provincia del Paraguay de la Compañía de Jesús [1673], 5 vols.. Madrid: Librería y Casa Editorial A. de Uribe y Compañía, 1897, liv. 9, cap. 20, vol. 4, p.72).

33 AGI, Quito, 189, "Memorial de Frei Manuel Cisneros" [1712], f. 4. 
seguissem relatando oferendas "ao demônio" depois de muitos anos de que os índios viviam em missões: o P. Maroni (1988 [1738], p.271), por exemplo, diz que os xamãs possuíam oratórios para "ayunos y penitencias en obsequio del Demonio"; nessas choças que se escondiam nos sertões, praticavam rituais que em parte imitavam os cristãos, evidência mais uma vez de sua inspiração diabólica, e faziam consultas ao inimigo comum sobre a sorte das próximas guerras. ${ }^{34}$

Os jesuítas preferiam manter em espanhol os termos positivos e centrais para a Igreja, como Deus, sacramentos etc., e lançar mão das palavras nativas para descrever o negativo. Por essa razão, por exemplo, no Vocabulario de la lengua Aymara (1612), do jesuíta Ludovico Bertonio, a palavra Deus foi mantida em espanhol e demônio foi traduzida no termo aymara para espírito mal, supayu (apud Green Jr., 2011, p.273). Como lembra Estenssoro Fuchs (2003, p.87, p.93, p.110), os missionários pós-tridentinos além de não reconhecerem que os índios possuíam algum conhecimento de Deus, quando o reconheciam, e notavam que havia uma palavra na língua indígena para referir-se ao Criador, não a adotavam, antes preferiam manter o termo Dios em espanhol, segundo o princípio da conversão como revelação de seu nome. Assim também os termos que diziam respeito às instituições e entidades próprias da Igreja romana, como igreja, missa, confessar, padre etc., não foram traduzidos, de modo a evitar qualquer reconhecimento formal à religiosidade indígena e a garantir o monopólio do religioso à Igreja.

Daí a preocupação dos padres em registrar as palavras utilizadas pelos índios para espíritos maléficos, agora identificados como o diabo. Entre os Encabellados, anota um cura, watí ou huati "quiere decir diablo y cuchillo. Cuando el indio dice: huati insiche, quiere decir: dame un cuchillo. Si dice pero huati raye, quiere decir: viene el diablo". ${ }^{35}$ A tradução deixava margem para ambiguidades, por não existirem nessas sociedades figuras

34 Mesmo entre os exemplares Guarani, ao que parece, alguns se submetiam a jejuns para tentar ver o demônio (TECHO, 1897 [1673], liv. 5, cap. 7, vol. 2, p.335-336).

35 NICLUTSCH, Francisco, S.J. Noticias americanas de Quito y de los indios bravos del Marañón [1781]. Quito: CICAME: Fundación Alejandro Labaka, 2012, p.155. 
que representassem a maldade absoluta, como o demônio cristão: os watí eram seres de conduta ambígua, protagonistas de narrativas numerosas, as mais delas com episódios risonhos. ${ }^{36}$

A metamorfose dos diversos espíritos que provocavam males no demônio cristão não deixava de incorrer em ambiguidades. Entre os índios de Maynas, os nomes desses espíritos variavam conforme a forma que assumiam e a variedade de línguas. Os Jevero efetivamente usavam o termo Papené para referirem-se ao "demônio" quando ele usava traje de espanhol. ${ }^{37}$ Outros chamavam os espíritos que causavam danos, logo identificados pelos padres como demônios, de Fensideque (ou Tensideque), mas o termo também era usado para referir-se aos espanhóis. ${ }^{38}$ Atalanqueis era o nome dado por alguns grupos indígenas a certos espíritos que assumiam a forma de "hombres sin cabeza que por el corte del cuello brotan fuego" ${ }^{39}$ Já o autor da "Arte de lengua" dos Tucano resolveu traduzir pelo termo "demônio" várias entidades que os índios chamavam de Coahuati, Zanaunhuati e Toaquati, mas o jesuíta não explicitava que tipos de espíritos eram esses e o que faziam. ${ }^{40}$

Não faltam, portanto, nos informes dos padres, referências aos demônios que atormentavam os naturais, e eles não raro aparecem com seus nomes em língua nativa. A política linguística dos missionários adotava o princípio segundo o qual os termos negativos não eram para a língua espanhola, mas para a indígena. Daí porque os nomes dos espíritos que atormentavam os neófitos seguiam sendo referidos em

36 Sigo aqui o trabalho de CIPOLLETTI, 1988, p.239-258, que acrescenta que o significado da expressão watí modificava-se de acordo com a palavra com que era combinado. Assim, por exemplo, compunha parte do nome dos xamãs, a exemplo de Watí So'koró, um xamã semilegendário, de quem se dizia haver logrado retornar do mundo dos mortos. Para o caso da Nova Espanha, ver DUVERGER, 1993, p.98.

37 ARSI, NR et Q, 14, f. 151-152v, "Relación de la misión de los maynas que enviaron los padres Gaspar Cugia y Lucas de la Cueva al P. Provincial Gaspar Sobrino”, Maynas, 25 out. 1640, f. 152.

38 ARSI, NR et Q, 12, i, Carta Annua, 1605, f. 9v; ARSI, NR et Q, 12, i, Carta Annua, 1606, f. 26.

39 ARSI, NR et Q, 12, i, “Carta Annua”, 1642-1652, Gabriel de Melgar, Quito, 1652, f. 41v.

40 NYPL, Obadiah Rich Collection, n. 30. "Arte de lengua de las Miciones del Rio Napo de la Nación de los infieles Quenquehoyos [...] Encavellados", 4 mai. 1753, f. 33v. 
vocabulários e informes, como parte de sua metamorfose no demônio dos cristãos. Era um processo não isento de ambiguidades, já que os missionários não podiam controlar o significado atribuídos às antigas entidades indígenas.

\section{A PRESENÇA FíSICA DO DEMÔNIO}

O esforço dos missionários por difundir a representação imagética do diabo materializou-se na sua difusão em pinturas dentro de igrejas, peças de teatro, livros e outras produções artísticas. ${ }^{41}$ Os jesuítas dedicaram não pouca atenção às formas e trajes em que os espíritos maus apareciam nas descrições feitas pelos índios. O objetivo dos padres era o de ter clareza das analogias possíveis, de modo a facilitar a introjeção da noção de demônio própria do cristianismo. Esperavam convencer os índios de que quem lhes causava esses males não era esse ou aquele espírito mau, mas o demônio dos cristãos. Incutir essa noção, e a de inferno a ela correlata, era imprescindível para manter a ordem nas missões e atrair a adesão dos nativos à doutrina cristã (Redden, 2008, p.124-125).

Realmente, eram muitas as formas assumidas pelo demônio, tal como percebido pelos índios. Uns diziam que usava "traje de espano", mas sua forma favorita parece ter sido a de papagaio, ou seja, "en figura de Guacamaya". ${ }^{42}$ Podia ainda assumir a forma de "gigante, tigre, culebrón [serpente gigante] y otras” (Maroni, 1988 [1738], p.172), ou

41 Artistas indígenas, quando estavam a cargo de pintar a imagem do demônio, faziam-no conforme os cânones esperados (MARTINI, 1990, p.336, p.355; GRUZINSKI, 2001, p.167-73, p.189-195). Guaman Poma de Ayala, por exemplo, no livro que ofereceu ao rei de Espanha em princípios do século XVII, incluiu uma imagem tradicional do demônio sob a forma de dragão (GAREIS, 2008, p.59). Terá sido de especial relevância, a esse respeito, a impressão, nas missões do Paraguai, em 1705, da obra De la diferencia entre lo temporal y lo eterno, do jesuíta Eusebio Nieremberg, publicada originalmente em Madrid, em 1640. Traduzido ao Guarani, o livro incluía um gravado que representa um demônio nos moldes clássicos, com chifres, asas e um tridente (WILDE, 2014, p.275).

42 AGI, Quito, 158, f. 246-257, "Relación de la misión apostólica”, Andres de Zarate, Quito, 30 out. 1735, f. 250; AGI, Quito, 158, f. 273-297, "Ynforme que haze a S.M. el P. Andres de Zarate", Madrid, 28 ago. 1739, f. 283v. 
ainda "Guangana [porco montês], Monos, Viracocha, con cara, pies, y manos blancos, lo demás negro, y la escopeta al hombro". ${ }^{3}$ "Gritos de animales", ouvidos à noite, eram a voz do demônio. ${ }^{44}$ Em certa paragem chamada Payarani, "entendió el padre había unos salvajes en opinión de los indios inmortales, son estos a manera de un niño de tres años todos con el pelo de siervos y algunos se han visto de solo un pie, otros de solo un ojo" ${ }^{4}$ "Dicen que tiene morada dentro de la tierra", anotou um padre. ${ }^{46}$ Uma vez apareceu sob a forma de um velho e disse "que aquellos padres traían las enfermedades". ${ }^{47}$ Ou preferia aparecer sob a forma de "un indio vestido de negro" que chamava os neófitos, e um deles "tuvo por cierto que era el demonio que pretendía hecharle de algún despeñadero" ${ }^{48}$ Também podia assumir a forma de recém-nascido mal formado, que os índios matavam na certeza de que fossem filhos dos espíritos maus ou, na leitura dos padres, do diabo (Mercado, 1957 [1684], t. 4, p.249).

Em resumo, parece que os jesuítas não tiveram dificuldades em introduzir a noção cristã de demônio, dado que os índios já possuíam sua própria concepção de espíritos que provocavam males. É provável, contudo, que sem os mesmos recursos que seus colegas que atuavam no Paraguai, os jesuítas de Maynas não puderam difundir mais amplamente a imagem clássica do demônio, e talvez tivessem que se contentar com a assimilação da versão mais popular, polimorfa, do inimigo comum. Daí as recorrentes referências dos neófitos não a um princípio abstrato, mas a uma entidade personificada, com traços humanos, cuja constante

43 MAGNIN (1988 [1740], p.475). Referindo-se à Inglaterra dos séculos XVI e XVII, escreve THOMAS: "Religious despair and prohibited desires were thus customarily personified in the crude form of a black man or a strange animal" (1997, p.475).

44 AHN, Jesuitas, leg. 251, n. 2, d. 3, "Relación de las cosas notables", Juan Magnin, Borja, 6 nov. 1743 , f. 8.

45 ARSI, NR et Q, 12, i, “Carta Annua”, 1642-1652, Gabriel de Melgar, Quito, 1652, f. 41v.

46 FIGUEROA, 1904, [1661] p.236-237.

47 AMICH, José, O.F.M. Historia de las misiones del Convento de Santa Rosa de Ocopa [1771], Lima: Milla Batres, 1975, p.65.

48 “Letras Annuas", 1608-1609, f. 40; PIÑAS RUBIO, 2008, p.100. 
presença indiciava certa familiaridade, e nisso não estavam distantes da mentalidade popular a respeito do demônio na Península Ibérica. ${ }^{49}$

Não poucas enfermidades, assim como outros males e danos, eram atribuídos, pelos índios, à ação concreta de entidades que podiam causar o mal, traduzidas pelos padres na figura do demônio. Refere o P. Gumilla (1955 [1741], p.246) que os índios do Orinoco, de modo geral, conheciam o príncipe das trevas, mas não lhe dedicavam culto algum, antes lhe temiam e atribuíam-lhe os males que sofriam. Faz ainda menção esse jesuíta a respeito de "los indios guamos, que le atribuyen sus enfermedades; de los mapoyes que le atribuyen los daños de sus sementeras; de los guaiquiries, que le tienen por autor de pleitos, y riñas; los betoyes, le atribuyen la muerte de todos los párvulos; y dicen que el demonio les rompe el pescuezo con gran secreto, para no ser sentido". ${ }^{50}$ Uma das personificações mais comuns permanecia ao lado dos doentes à espera de sua morte. Testemunhas ouvidas pelo P. Magnin disseram que, sem ser chamado, o diabo acudia à casa em que padecia um moribundo: "tendía ay su jamaca, sentabase en ella mientras los demás amontonados en un rincón de miedo, apenas se atrevían a continuar el resuello"; quando o paciente despedia-se de sua alma, o estranho visitante "doblaba su jamaca, y sin decir palabra, se salía puertas afuera echando por los ojos centellas y fuego. Avia moribundos que porque no hiciera daño a sus hijos se los recomendaban". ${ }^{1}$

49 FLORES ARROYUELO, 1985, p.26. No Orinoco, um missionário recolheu a informação seguinte: "se dice que el mismo demonio, mintiendo figuras varias, baja hasta ellos a veces por la parte superior de las casas" ("Misión del río Orinoco en el Nuevo Reino", Gaspar Beck, 1684, In: REY FAJARDO, 1974, vol. 2, p.169). Também fazia companhia aos índios quando se internavam pelas matas, segundo apurou o P. Zarate: "Cuando van solos por los bosques le ven de repente a su lado, y los acompaña sin que le puedan apartar de si” (AGI, Quito, 158, "Relación", Andres de Zarate, Quito, 30 out. 1735, f. 250-250v). O mesmo diz o P. Maroni (1988 [1738], p.378).

50 Era amplamente difundida entre os demonólogos a crença de que as doenças eram causadas pela influência de demônios - efetivamente, por meio do sopro de um bruxo e de certas magias simpáticas - e que a medicina, por atuar sobre causas naturais, combatia aquelas ações malignas no mesmo terreno, CLARK, 1997, p.196. Conjuros e exorcismos podiam extirpar os espíritos estranhos causadores desses males, THOMAS, 1997, p.183.

51 AHN, Jesuitas, leg. 251, n. 2, d. 4, “Breve descripción”, Juan Magnin, 1740, f. 18; “Entra de 
É assim que o visitador Zarate referia, em 1739, que um dos trabalhos dos padres era expulsar o demônio, que se deixava ver, em pessoa, em vários pueblos: "se dejó ver en figura orrible en algunas casas de los párranos, desenterrando a los difuntos, y cargando con sus cadáveres podridos a lo más ynterior del monte, con horror, y sumo miedo, de los que lo vieron". Dedicava-se, inclusive, a disseminar epidemias: "Casi al mismo tiempo en las casas de los Zamuras, y Yaies, Yameos, se dejó también ver el demonio, en figura de Guacamaya, amenazando los con la muerte con bozes articuladas; y de echo, dentro de pocos días se fueron muriendo casi todos de repente, sin saberse de que mal".52

Mesmo o ilustrado P. Veigl (2006 [1785], p.230-231), já nas décadas finais do século XVIII, reafirmava a existência material do demônio: seguindo as formulações do P. Acosta, não deixa de enfatizar sinais da existência material do diabo: "todas [las naciones] están de acuerdo que lo perciben como fantasma, por lo general invisible, pero que puede hacerse visible en la forma que le convenga, y que supera en poder al ser humano; por lo demás, no se sabe con certeza si le conceden rango divino". Diz ainda que o temiam porque realmente podia causar danos.

Embora a crença nos "aparecidos", essas almas que, por uma razão ou outra, mas sempre com o aval de Deus, retornam por algum tempo ao mundo dos vivos, fosse compartida por religiosos europeus, os missionários não hesitaram em atribuir algumas aparições, atestadas pelos índios amazônicos, às maquinações do diabo (Cf. Delumeau, 2012, p.104, p.110-111; Thomas, 1997, p.587). A demonização dos aparecidos, ao que parece, terá predominado para os casos anteriores à chegada dos padres, como escreve o P. Maroni (1988 [1738], p.283): "el Demonio solía dejarse ver en traje y figura del difunto". Outro missionário anotou que "las almas de sus difuntos o el diablo, solían volver

improviso a sus casas, siéntase en sus redes, y si ay algun moribundo no se aparta del hasta que espie" (AGI, Quito, 158, "Relación”, Andres de Zarate, Quito, 30 out. 1735, f. 250-250v). Notícia semelhante, entre os Yameo, sobre o demônio que aguardava até que o doente expirasse na carta de Pablo Maroni a Angel Maria Manca, procurador das missões, La Laguna, 21 dez. 1731 (MARONI, 1988 [1738], p.378).

52 AGI, Quito, 158, "Ynforme”, Andres de Zarate, Madrid, 28 ago. 1739, f. 285. 
de noche a sus casas, con ruidos: pero ya esto le quitó con las cruces que se han puesto". ${ }^{3}$

Já pelos anos 1760, os jesuítas seguiam relatando casos de aparecidos e a presença física do demônio. Entre os Chamicuros, diz o P. Widman, precisamente no ano de 1760, sucedeu que, indo uma moça recém-casada banhar-se sozinha ao fim da tarde, apareceu-lhe certa índia Juana, que havia morrido alguns dias antes sem confissão, e lhe disse que a acompanhasse, que ali onde estava havia muito milho, e ao dizer isso lhe deu um golpe nas costas e lhe lançou ao solo. A moça voltou correndo para a sua casa e, em pouco tempo, lhe apareceram convulsões e dores que lhe faziam gritar "como endemoniada". O missionário procedeu ao exorcismo com uma estampa de São Xavier que trazia e a confessou, mas não pôde quitar as dores de cabeça que sentia. Nesse caso, parece certo que o jesuíta não duvidava de que realmente a índia tivesse visto a "aparecida" Juana, e atribuiu o episódio à efetiva atuação do demônio, que somente o recurso ao exorcismo podia superar. ${ }^{54}$ Para os religiosos católicos, como lembra Delumeau (2012, p.115), a morte trágica em meio a um rito de passagem (crianças não batizadas, afogamentos ou, como no presente caso, uma pessoa que deixou de receber o sacramento da penitência), quase sempre podia produzir vampiros e outros demônios. Parece ser esse o caso, sendo certo que, mais uma vez, a Igreja procurava enquadrar os aparecimentos em seu propósito militante.

Do mesmo modo que os tratados de demonologia condenavam a adivinhação, a premonição e as artes divinatórias como manifestações do pacto demoníaco (Clark, 1997, p.462-467), assim também, na opinião dos jesuítas que atuavam no Orinoco, os índios consultavam o diabo por meio de uma espécie de chicha e toque de tambores: "A menudo los más viejos se juntan, ya cantando a la manera de los clérigos, ya tocando tamboriles de tortuga, y pasan la noche íntegra para saber

53 Comillas/CP, Serie Negra, Cuaderno n. 108, f. 107-123, "Letras Anuas de la Misión de la Trinidad de Cunivos", f. 110.

54 Comillas/CP, Serie Negra, Cuaderno n. 108, "Aditamento a los Apuntes", Widman, c. 1762, f. 103. 
del demonio el futuro". ${ }^{55}$ Um informe de 1621, que resume as expedições encarregadas pelo governador Alonso de Miranda, diz que certa bebida à base de bejuco fazia os índios especialistas perderem o juízo, "y entonces el demonio les representa al propósito de lo que ellos queren". Também usavam de canudinhos de tabaco, "que tomándolo a des oras de la noche tienen pacto con el demonio y de si adinan lo que quieren los más". Não se tratava, contudo, de um culto formal, pois "cierto es que no tienen otro dios más que su vientre". ${ }^{56}$

É preciso enfatizar, uma vez mais, que a demonização não era tão somente uma forma de negação das culturas indígenas. Os jesuítas atribuíam a resistência cultural à conversão e as consequentes revoltas não a qualquer indisposição intrínseca aos naturais, mas à influência externa, sempre removível, do demônio, que agia através de seus mediadores, os feiticeiros (Reff, 1993, p.310; Nicoletti, 1999, p.132; Bernabéu Albert, 2000, p.157).

Em Maynas, os jesuítas frequentemente diziam que tal ou qual revolta fora "movida por el demonio" e que os rebeldes estavam "instigados del Demonio". 57 "Irritado el demonio de que se le quitasen tantas almas", escrevia o provincial dos franciscanos sobre uma revolta que teve lugar por volta de 1686, nas missões mais próximas ao rio Amazonas, "levantó entre aquellos neophitos una implacable conspiración contra los religiososo conversores, y sacudiendo el suave yugo de la doctrina”, deram morte aos sacerdotes, leigos e donatos que ali se encontravam. ${ }^{58}$ Houve uma deserção geral para os montes porque lhes havia "cegado el

55 Acrescenta o P. Beck, a respeito do consumo da droga Hyopa: "Por las narices, valiéndose de un instrumento cóncavo de madera, beben Hyopa (está confeccionado de ciertas semillas fortísimas) y así se embriagan y pierden el sentido, de tal manera que no pueden entrar, más aún ni moverse, y cuando sueñan en esta borrachera hyópica o 'inspiración' lo toman por un oráculo" ("Misión del río Orinoco en el Nuevo Reino", Gaspar Beck, 1684, In: REY FAJARDO, 1974, vol. 2, p.169).

56 ARSI, Brasile, 9, "Relación de las nuevas provincias que por el río Marañón se an descubierto", 1621, f. 5.

57 AGI, Quito, 134, n. 10, "Informe del P. Provincial de San Francisco de Quito, sobre las misiones de Su religión”, Bartolomé de Alcano, post. a 18 jul. 1739, f. 2.

58 AGI, Lima, 532, Carta de Fr. Pedro Magariños a S.M., Lima, 22 abr. 1750, f. 6v. 
demonio" ${ }^{59} \mathrm{O}$ príncipe das trevas colocava obstáculos "para impedir la conversión", como o ódio que os índios nutriam dos soldados espanhóis, indispensáveis para a escolta dos padres. ${ }^{60} \mathrm{O}$ comum inimigo chegava, inclusive, a sugerir o tratamento que se devia dar ao padre: "el diablo les sugiere en su tomada de Hyopa que los padres son la causa [de los males], y que se les debe castigar con el azote, los suplicios y la muerte". ${ }^{61}$

Sendo a revolta causada por um inimigo externo, a natureza frágil, humana, do índio ficava preservada e a possibilidade de reconciliação mantida em aberto. Um artificio retórico, talvez, mas que mantinha o terreno comum de negociação em que se erigiam as missões. O mesmo passava com outras ordens religiosas: pelo ano de 1634, uma entrada dos franciscanos aos Tupinambás fracassava miseravelmente, com morte da escolta de soldados espanhóis, em ação "movida por el demonio". ${ }^{62}$ Mais tarde, quando uma nova leva de missionários resolve extirpar alguns aspectos da primeira evangelização, como a manutenção da poligamia, uma série de levantamentos "instigados del Demonio", ocorridas em 1721, resultaram na morte de vários freis. ${ }^{63}$ Índios residentes em Borja, já munidos de ferramentas e cultivos, cegados pelo demônio, desertavam deixando tudo para trás. ${ }^{64} \mathrm{O}$ P. Uriarte (1986 [1775], p.127-128), ao constatar que um grupo tramava a sua morte e a destruição do pueblo, disse aos seus neófitos: "No oigáis al demonio, que os quiere apartar de los Padres para llevaros al infierno". Alertou ainda que, se alguns o quisessem fazer dano, contava com escopeta, sabre e pistola para defender-se.

59 AHN, Jesuitas, leg. 251, n. 2, d. 3, "Relación de las cosas notables", Juan Magnin, Borja, 6 nov. 1743 , f. 7.

60 “Petición hecha al Virrey”, del P. José de Cases, 1668 (In: JOUANEN, 1941, vol. 1, p.485).

61 “Misión del río Orinoco en el Nuevo Reino", Gaspar Beck, 1684, In: REY FAJARDO, 1974, vol. 2, p.181.

62 AGI, Quito, 134, n. 10, "Informe del P. Provincial de San Francisco de Quito, sobre las misiones de Su religión”, Bartolomé de Alcano, post. 18 jul. 1739, f. 2.

63 AGI, Quito, 134, n. 10, "Informe del P. Provincial de San Francisco de Quito, sobre las misiones de Su religión”, Bartolomé de Alcano, post. 18 jul. 1739, f. 6v.

64 AHN, Jesuitas, leg. 251, n. 2, d. 3, "Relación de las cosas notables", Juan Magnin, Borja, 6 nov. 1743 , f. 7. 
A ideia de uma servidão coletiva dos indígenas a Satanás estava conectada com a compreensão de que o canibalismo era uma instituição cultural muito estendida entre os índios. Cieza de León, ${ }^{65}$ cronista da conquista do Peru, por exemplo, refere que os nativos eram muito hábeis em preparar pedaços de corpos humanos como se fossem chouriços (morcillas) e linguiças (longanizas). Contudo, apesar do repúdio às práticas nativas, Cieza de León considerava que o culpado de tudo era o diabo: os corpos esquartejados eram normalmente colocados ao lado dos altares dedicados a Satanás. O recurso à demonização era o que permitia tornar inteligível um ritual cujo significado permanecia opaco aos adventícios. A mutilação dos corpos era uma prática associada ao demônio porque o inferno era descrito, no início da Idade Moderna, como um lugar onde os condenados eram permanentemente torturados e esquartejados (Cañizares-Esguerra, 1998, p.127-131).

Quando os missionários eram mortos e devorados pelos índios, o discurso jesuítico não duvidava em atribuir esses eventos à emulação direta do demônio. E do mesmo modo, a decapitação do P. Francisco de Figueroa pelos Cocamas, Chipeos e Maparinas, em 1666, ficou marcada como um evento crucial na luta contra a presença efetiva do demônio na Amazônia. ${ }^{66} \mathrm{O}$ procurador Manuel Rodríguez (1684, p.288), por exemplo, exaltava o martírio daquele padre, pois "fue su muerte para confusión del demonio, viendo la Corona, que ganaba su mayor enemigo en aquellos montes". Como escreveu certo padre a respeito do martírio de missionários que atuavam no Orinoco em 1684, os ataque dos índios - que queimaram as casas e profanaram objetos sagrados foram movidos "por el Principe de las Tinieblas, que vía ya la batalla que se le hazía por los operarios evangelicos y temiendo ser desposeído de el dilatado imperio de tanto gentilismo, con titulo de paz, [los indios]

65 CIEZA DE LEÓN, 2005 [1553], p.78.

66 AGI, Quito, 20A, n. 32, Memorial do P. Lucas de la Cueva em que solicita ajuda de Custo, c. 1666, f. 1. Ainda sobre o martírio do P. Figueroa, cf. VELASCO, Juan de, S.J. Historia moderna del Reyno de Quito y Crónica de la Provincia de la Compañía de Jesús del mismo Reyno [1788]. Quito: Impr. de la Caja del Seguro, 1941, p.339-341 e JOUANEN, 1941, vol. 1, p.451-455. 
mataron a golpes de macana, a los doctrineros". Diz ainda que os corpos dos padres Gaspar Bech e Ignacio Thoebast foram mutilados e comidos; e que o do P. Ignacio Tiol foi poupado apenas porque era já homem de idade e penitente. ${ }^{67}$

Uma das tarefas centrais do trabalho dos missionários era, portanto, a de expulsar o demônio da dominação que exercia sobre os índios. ${ }^{68}$ Para tanto, contavam com várias ferramentas (Nicoletti, 1999, p.134). O primeiro passo era erigir algumas cruzes, que marcavam o território em posse dos cristãos. ${ }^{69}$ Se não bastassem para exorcizar os demônios, podia-se recorrer à água benta (Maroni, 1988 [1738], p.293). Em todo caso, o batismo era o sacramento par excellence que permitia expulsar os demônios. ${ }^{70}$ Em relação aos já referidos homens sem cabeça: "Estos dicen los indios católicos que antes que se cristianasen eran muy insolentes contra los mismos indios y que después de bautizados los reconocen más respectivos". ${ }^{71}$ Uma índia, ao revalidar o batismo que os antigos clérigos que atuavam em Borja lhe haviam ministrado, como evidência do exorcismo, pariu um monstro "a manera de sapo de muchas manos y piés” (Mercado, 1957 [1684], t. 4, p.153-154). Também a penitência

67 ARSI, NR et Q, 15, i, f. 142-144v, “Memorial”, Juan Fernández Pedroche, Santa Fe, 24 nov. 1687, f. $142 \mathrm{v}$.

68 A possessão demoníaca era uma realidade palpável para não poucas pessoas na Europa ocidental. Era possível reconhecer que um espírito maligno se havia alojado em um indivíduo pelos estranhos efeitos físicos e morais dessa intrusão: podia apresentar histeria, convulsão, contorções, vômitos, paralisia etc.; sua voz comutava-se numa voz gutural, emitia blasfêmias e falava em línguas desconhecidas da vítima. A partir do século XVI, acreditava-se que as bruxas pudessem causar a possessão demoníaca em alguém (THOMAS, 1997, p.477-492).

69 AGI, Lima, 407, “Breve noticia”, Pedro Marbán, 1700, f. 4v. Sendo certo que se tratava do "símbolo de la victoria del cristianismo y de la expulsión de los demonios infernales" (SEPP, Antonio, S.J. Continuación de las labores apostólicas [1709]. Buenos Aires: Editorial Universitaria de Buenos Aires, 1973, p.195); cf. SEED, 1995, p.100-148, sobre o uso de cruzes nas cerimônias de posse dos portugueses.

70 MAGNIN (1998 [c. 1740], p.208). Embora os religiosos concordassem que, no batismo, o neófito fosse convidado a participar do mistério da imersão de Cristo no abismo da morte e da emersão no esplendor de sua ressurreição, houve querelas em relação ao seu uso como forma de exorcismo em âmbito americano, cf. PARDO, 2004, p.25-26, 172, n. 24.

71 ARSI, NR et Q, 12, i, “Carta Annua”, 1642-1652, Gabriel de Melgar, Quito, 1652, f. 41v. 
era considerado um sacramento que exorcizava eficazmente: "En los confesionarios hacen cruda guerra a los demonios". ${ }^{72}$

O caso dos Yameos demonstrava a importância, para os jesuítas, do batismo como forma de extirpar os demônios. O sacramento do batismo manifestava todo seu poder ao expulsar o comum inimigo: aqueles que o recebiam "se ven del todo libres de las persecuciones deste cruel enemigo, como lo confiesan todos". Um jovem em especial, chamado Antonio, intérprete dos missionários, afirmava que, morto seu pai, havia encomendado sua alma ao diabo, "q. hallaba presente para que le acompañase y cuidase del en toda su vida, lo que fielmente executó el enemigo". O filho arrependeu-se, mas continuava atormentado por espíritos: "Esto duró hasta se servir el agua del S.to Baptismo, porque desde ese tiempo se desapareció y protesta el joven de nunca mas averlo visto". Finalmente, em um passo revelador, afirmava o P. Zarate que, como estratégia de evangelização, o conhecimento prévio do demônio pelos índios era utilizado com vantagem pelos missionários: "Este conocimiento que tienen del enemigo común ha sido después por providencia de Dios uno de los medios más eficaces que ayan conducido para darles alguna noticia palpable de nuestra religión". ${ }^{73}$

Aparentemente, a demonização era tão somente mais uma das representações negativas que recaíam sobre os índios, mas em realidade o significado da insistência dos missionários em ver o demônio na América não se esgotava aí. Demonizar, em vez de retirar a humanidade do Outro, afirmava-a. Atribuir ao demônio a responsabilidade pelos martírios e destruição das missões tornava os índios tão humanos quanto os europeus, igualmente sujeitos à tentação e à influência maligna do inimigo comum. Demonizar, portanto, mantinha aberta a possibilidade de reconciliação (Torres-Londoño, 2007, p.199). O status deles como

72 ARSI, NR et Q, 13, i, f. 3-35, "Relación annua de la Provincia del Nuevo Reyno de Granada desde el año de 1655 hasta el año de 1660", por Hernando Cabero, Santa Fe, 20 fev. 1660, f. 3v; cf. também: Ignacio Jiménez ao vice-provincial de Quito, Roamainas, 13 mar. 1668, In: Jouanen, 1941, vol. 1, p.480.

73 AGI, Quito, 158, “Relación”, Andres de Zarate, Quito, 30 out. 1735, f. 250-250v. 
homens, como filhos do mesmo Deus, crescia à medida que suas práticas e crenças eram situadas em certa igualdade com as dos cristãos. ${ }^{74}$

Demonizar significava aproximar para compreender; tornar o estranho parecido com o que já se conhecia. Essa preocupação sobressai na obra do P. Acosta, em que o demônio era empregado para explicar aqueles traços rituais ou míticos mais contrastantes e distantes em relação ao catolicismo, como a sacralização generalizada da natureza, o politeísmo, os usos premonitórios, os sacrifícios humanos etc.; traços anômalos aproximados pela lente missionária aos dos povos da antiguidade clássica ou bíblica ou aos dos camponeses europeus (Pagden, 1988, p.206, p.235-236; Pino Díaz, 2002, p.143, p.152). A demonologia emergia, portanto, como ciência do Outro: a "heterologia" - no dizer de Michel de Certeau - como tentativa de nomear e classificar o Outro, no âmbito de "uma 'cultura' assombrada pela sua exterioridade 'selvagem", o que não raro se fez com os elementos negativos e detratores por excelência dessa cultura (Certeau, 1993, p.325; Mello e Souza, 1993, p.25) ${ }^{75}$

Não era incomum que os religiosos verificassem semelhanças e analogias entre ritos e concepções religiosas indígenas e o cristianismo. Nas primeiras décadas de evangelização, os freis entendiam-nas como sinais milenaristas de que o terreno já estava preparado para a cristianização de todo o mundo. Assim, inicialmente, os franciscanos, artífices da primeira evangelização, compreenderam que os elementos

74 GARCÍA GAVIDIA, 1995, p.218 s.s. Ver também: PINO DÍAZ, 2002, p.143.

75 O missionário em geral atribuía costumes que não compreendia à ação efetiva do demônio: entre os Pano, por exemplo, era comum a mutilação do clítoris porque "el diablo induce a esta pobre gente a mil boberías" (Comillas/CP, Serie Negra, Cuaderno n. 108, f. 49-67, "Apuntes de las cosas más memorables", Adan Widman, c. 1762, f. 65). Em certo sentido, demonizar parecia implicar em desistir de analisar e entender racionalmente, em sua lógica interna, determinado aspecto cultural indígena. Frei Durán (1967 [1581], vol. 1, p.236), vendo-se desprovido de um conhecimento suficiente da língua náhuatl, escreve: "he oído semejantes días cantar en el areito unos cantares de Dios y del santo, y otros mezclados de sus metáforas y antiguallas, que el demonio que se los enseñó sólo los entiende". Contudo, o arcabouço teórico da Igreja, desenvolvido durante a Idade Média, e que permitiu localizar e enquadrar as práticas e concepções mágicas e pagãs opostas ao cristianismo, foi transferido para o Novo Mundo, onde ajudava a organizar a leitura de um mundo distinto, mas permeável por suas inúmeras analogias, RAGON, 1988, p.173. 
da religiosidade pré-hispânica podiam eventualmente ser utilizados no trabalho missionário. Mas a ortodoxia que emergiu do Concílio de Trento não pretendia fazer concessões e reconhecimentos desse tipo (Ricard, 1986, p.97-101; Estenssoro Fuchs, 2003, p.186-187).

As analogias entre a religião pré-hispânica e o cristianismo foram definidas pelo P. Acosta como imitações demoníacas, embora o jesuíta não deixasse de reconhecer a utilidade de certas práticas e concepções como preparação para o cristianismo. Mas em um sentido bem preciso, que não fazia concessões à religiosidade nativa: tão pesado era o jugo de Satanás, que seus escravos o toleravam como castigo e viram uma doce libertação na religião que agora se lhes predicava. ${ }^{76} \mathrm{~A}$ análise do $\mathrm{P}$. Acosta sobre o mundo indígena contrastava o natural e o sobrenatural (Cervantes, 1996, p.47). Em relação ao natural (expressões culturais), Acosta (2008 [1590], liv. 6, cap. 1, p.204) se esforçava por sublinhar a bondade natural das culturas indígenas: "en lo que no contradicen a la ley de Cristo y de su santa iglesia deben ser gobernados conforme a sus fueros, que son como sus leyes municipales. Por cuya ignorancia se han cometido yerros de no poca importancia, no sabiendo los que juzgan ni los que rigen por dónde han de juzgar y regir sus súbditos". Por outro lado, em relação à esfera do religioso, se havia rituais e concepções que se assemelhavam aos dos cristãos, era porque o diabo procurava construir no Novo Mundo a sua anti-Igreja, com templos, confissão, rituais de purificação, eucaristia e mesmo certa imitação da Santíssima Trindade que havia em Cuzco, onde três estátuas representavam o senhor Sol, o filho Sol e o irmão Sol (Acosta, 2008 [1590], liv. 5, cap. 28, p.192; cf. MacCormack, 1991b, p.269). A percepção dos Concílios Provinciais era a de que era preciso conhecer para distinguir. O quadro teórico formulado pelo Terceiro Concílio Limenho e difundido nas obras de Acosta seguia sendo o modelo utilizado pelos missionários para avaliar

76 "El yugo pesadísimo e incomportable de las leyes de Satanás, y sacrificios y ceremonias, ya dijimos arriba que los mismos indios estaban ya tan cansados de llevarlo que consultaban entre sí de buscar otra ley y otros dioses a quien servir. Así les pareció y parece la ley de Cristo justa, suave, limpia, buena, igual y toda llena de bienes" (ACOSTA, 2008 [1590], liv. 7, cap. 28, p.271). 
e distinguir as práticas indígenas que deviam ser toleradas e as que deviam ser reprimidas e extirpadas. ${ }^{77}$

Os primeiros jesuítas que atuaram em Maynas notaram que alguns grupos praticavam um tipo de confissão que os religiosos não hesitaram em descrever como uma emulação do diabo: "es de admirar que el demonio introdujese entre estos bárbaros un modo de confesión que hacen con sus sacerdotes", registra a carta ânua de 1652, "y el demonio mismo se indigna tanto de la falsedad de los penitentes que cuando estos omiten alguna culpa se la manifiesta al bárbaro confesor que al falso penitente le dice si si lo que quiere decir mientes y luego hace se le entre una ranilla o sapo entre el cuello y el pecho donde paseándose con ofensión del miserable penitente le hace manifestar cuanto ocultó su simulación".78

Outra prática inspirada pelo demônio era a imitação, por parte dos xamãs, do ofício sagrado dos padres. Na resistência movida pelos feiticeiros, como assinala Rípodas Ardanaz (1984, p.204), não comandava tanto um desejo pelo retorno das antigas práticas, mas por uma apropriação autônoma dos elementos do catolicismo no âmbito do universo simbólico indígena. ${ }^{79} \mathrm{Na}$ Amazônia portuguesa, os jesuítas verificaram a atuação dos xamãs como "missionários" paralelos. O padre Bettendorff fornece um exemplo ao descrever a atuação dos xamãs em Tapuitapera (hoje Alcântara, Maranhão), uma das missões mais antigas da colônia.

77 Como afirmava o P. Acosta (2008 [1590], liv. 5, cap. 31, p.198): "no sólo es útil sino del todo necesario que los cristianos y maestros de la ley de Cristo sepan los errores y supersticiones de los antiguos, para ver si clara o disimuladamente las usan también agora los indios". Cf. RICARD, 1986, p.109 e BERNAND; GRUZINSKI, 1992, p.167.

78 ARSI, NR et Q, 12, i, “Carta Annua”, 1642-1652, Gabriel de Melgar, Quito, 1652, f. 41v.

79 Um padre verificou que o inimigo comum fomentava a emergência de uma Igreja paralela, em que os índios da cidade de Ancerma, sob a jurisdição do Colégio de Popayán, eram estimulados a voltar aos antigos costumes e a assimilar uma versão distorcida da doutrina cristã: "el demonio en voz sensible predicaba a los indios en cierta ranchería desierta donde se juntaban los del pueblo y como a indios que tenían algún conocimiento de Dios los engañaba el demonio para reducirlos a sus antiguas supersticiones no negándoles absolutamente el verdadero Dios". Tinham como predicadores ninguém menos que Adão e São Pedro: "Adán les decía que era para enseñarlos el modo de cultivar las tierras. San Pedro para darles la doctrina necesaria para su salvación" (Carta Annua, 1642-1652, f. 37, PIÑAS RUBIO, 2008, p.138). 
O padre foi informado que, naqueles arredores, havia xamãs que ouviam confissões, ofertavam pão como se fosse hóstia, falavam com o diabo, convocavam os índios para danças e cantos e falavam de um caminho único para a salvação. ${ }^{80}$

Ao que parece, os xamãs e a crença em seu poder nunca terão sido desterrados completamente pelos padres. No Orinoco, mesmo depois de reduzidos os naturais, os xamãs constituíam uma sociedade paralela e exclusiva que os padres não podiam dissolver. Certo xamã chamado Tulujay vivia oculto dos missionários e mantinha uma escola secreta e sumamente exclusiva, à qual concorriam índios de todas as partes da Amazônia. Exclusiva porque eram poucos os que persistiam nos seus ensinamentos, primeiro porque custavam caro; depois porque lhes obrigava o moján a um rigoroso jejum de 40 dias. Os que cumpriam a quarentena, recebiam umas pílulas especiais que, segundo a opinião geral, atuavam como antídoto contra todo o gênero de veneno e guardava o corpo dos iniciados contra seus êmulos e inimigos. Tendo o P. Gumilla (1955 [1741], p.248-250) questionado um cacique cristão, cujo comportamento era exemplar, por apoiar como ninguém o trabalho dos padres, por que se havia submetido aos ensinamentos daquele moján, teve como resposta que se os espanhóis carregavam armas consigo para sua defesa, não via o cacique problema em ter essas pílulas em seu estômago para estar curado e fortificado contra qualquer inimigo. ${ }^{81}$

80 ARSI, Brasile, 9, f. 259-267v, “Carta ânua”, João Felipe Bettendorff a João Paulo Oliva, São Luís, 21 jul. 1671, f. 264, apud ARENZ, 2014, p.78.

81 Embora isso fosse raro, alguns jesuítas atenuaram a demonização de certas práticas que viam como análogas ao cristianismo e preferiram tratá-las como um presságio ou preparação para que os naturais recebessem a verdadeira fé. Como escreve o P. Magnin, em referência à espécie de batismo praticada entre os Omaguas e Pebas, "tal qual señal, parece, q. se halla entre algunos de la ley de D.s, y de la venida de X.o”. Entre os Omaguas, havia uma celebração em que as mulheres buscavam água em um rio próximo; a criança a ser batizada era levada em procissão pela aldeia; e o padrinho lançava água sobre ela e lhe dava um nome. Entre os Pebas, a madrinha oferecia coca à afilhada, aos pais e demais convidados; seguiam-se bebedeiras e danças. Do mesmo modo, os Pebas faziam "procesiones, cargando en lugar de cruz, a su Caeri, estatua de balsa, q' hacen, sin pies, ni manos, adornada de varias plumas, y cascabeles, acompañando todo eso con correrías, flechazos, ruidos, pinturas, baños, algazara, canciones, y varias otras invenciones" (AHN, Jesuitas, leg. 251, n. 2, d. 4, “Breve descripción”, Juan Magnin, 1740, f. 20-22). 


\section{OS XAMÃS E O DEMÔNIO}

A opinião dos jesuítas dividia-se entre aqueles que acreditavam que os xamãs hauriam algum poder graças a consultas e tratos que tinham com o demônio e os que simplesmente consideravam-nos charlatães, cujos embustes visavam apenas enganar os mais simples e alcançar prestígio nas comunidades. Ao longo do tempo, verifica-se uma tendência nos escritos dos jesuítas de passar da primeira posição à segunda, de modo que o mais comum, nos textos produzidos no exílio, era uma posição mais racional, que considerava os xamãs apenas embusteiros. Mas essa regra nem sempre se confirmou e houve exceções importantes. ${ }^{82}$

Já em 1639, os franciscanos que haviam descido o Amazonas estavam certos de que os xamãs consultavam com o demônio, "de quien reciben oráculos", embora também tivessem visto que enganavam os índios. ${ }^{83}$ Na opinião do franciscano frei Frei Manuel Cisneros, os xamãs interpretavam sonhos, algo que "a introducido el demonio" ${ }^{44}$ Já tardiamente, o P. Maroni (1988 [1738], p.172-173), em suas "Noticias secretas" de 1738, em que tantas vezes o demônio era referido como protagonista dos problemas sofridos pelas missões, observava que "los moanes y hechiceros le consultan [al maligno] y dél aprenden el arte no sólo de curar y adivinar, sinó también de causarles las enfermedades, pestes y otros desastres que regularmente los atribuyen". E prossegue referindo que, para adivinhar, bebiam o suco do floripondio branco ou do bejuco chamado ayahuasca, "ambos muy eficaces para privar de los sentidos, y aun de la vida [...]; ya medio borrachos, cantando propalan lo que veen, o lo que sueñan, o lo que los representa el Demonio, y esto es lo que escuchan con ansia y celebran todos los demás".

82 BERNÁBEU ALBERT, 2000, p.162, atentou para a diferença de opiniões ao longo do século XVIII.

83 ARSI, NR et Q, 15, i, f. 274-279, “Relación del descubrimiento del Río de las Amazonas, oy Río de San Francisco de Quito, y declaración del mapa em donde está pintado" [Alonso de Rojas, 1639], f. 277v.

84 AGI, Quito, 189, “Memorial de Frei Manuel Cisneros", 1712, f. 4. 
Por outro lado, são também numerosos os testemunhos de uma atitude cética em relação aos xamãs. Já o P. Figueroa (1904 [1661], p.236-237), em seu informe de 1661, afirmava que os xamãs "finjen que el demonio les habla, para acreditarse en el officio y por engañar y sacar la paga que les dan, [y] cobrar autoridad". O P. Mercado (1957 [1684], t. 4, p.249), escrevendo em meados da década de 1680, não admitia que os xamãs tivessem poder algum: eram embusteiros e não falavam com o demônio, antes fingiam fazê-lo para enganar os outros e obter pagamento. $\mathrm{O}$ autor da "Arte de lengua" dos Tucanos, escrevendo em 1753, era mais prudente ao afirmar que "estos Vinia Paines son como los saçerdotes gentiles: cantan y llaman al Diablo para adivinar cosas futuras [y] aun precentes urtos, y curar enfermos, para siembras y otros embustes y como el demonio coopera en estas peticiones, lo cren a estos Vinia Paenistas y assi son temidos, y obedecidos entre ellos". Assim, considerava os xamãs embusteiros, mas o diabo favorecia os embustes, razão pela qual sua influência nas missões não era de desprezar-se. ${ }^{85}$ Apesar de tudo, mesmo os jesuítas que atribuíam o poder dos xamãs ao artifício e ao engano, não deixavam de ter em consideração a possibilidade de que o demônio colaborasse com aquelas ações que, de um modo ou de outro, lhe podiam trazer benefícios.

Em última instância, a opinião que parece predominar nos escritos de jesuítas sobre o poder dos xamãs era a de que se tratavam de charlatães e que, em realidade, não falavam com demônio algum. Se um ou outro xamã efetivamente pôde tratar com o diabo, o certo era que, em geral, os feiticeiros fingiam e enganavam os índios comuns para obter pagamento pelo que lhes davam ou diziam, bem como para obter autoridade e respeito na comunidade. Para conseguir essa estimação usavam de vários embustes, como meter-se a sós dentro dos toldos; retirar-se aos rincões secretos e escuros e fazer algumas cerimônias de falar entre dentes umas vezes, e outras de cantar, dando a entender que chamavam

85 NYPL, Obadiah Rich Collection, n. 30. “Arte de lengua", 4 mai. 1753, f. $23 \mathrm{v}$. 
o demônio e que este lhes revelava o futuro. ${ }^{86} \mathrm{O}$ fato de que os índios amazônicos acreditassem que as doenças eram produto de feitiços acabava por reforçar a figura do xamã. Em geral, os naturais lançavam a culpa ao feiticeiro, ou a certo índio que passou por sua casa, a quem o defunto negara alguma coisa. Um sopro ou uma pedra dirigidos ao alvo do feitiço já bastavam para provocar uma doença ou outro dano. Era assim que, na opinião dos jesuítas, o demônio mantinha os índios atados a uma permanente rede de inimizades (Mercado, 1957 [1684], t. 4, p.250).

A posição dos jesuítas pouco se alterou nas últimas décadas do século XVIII. O poder dos xamãs era considerável, tanto mais porque os índios atribuíam todos os sucessos, enfermidades, mortes, êxito em colheitas, caçadas e no que fosse, à magia dos bruxos. O P. Veigl, espírito ilustrado, não via no que faziam os xamãs mais do que mera trapaça: "Estos pretendidos brujos se jactan de tener poder sobre las serpientes, los tigres, las enfermedades, las tempestades, engañando a los simples con su facilidad de palabra y sus trucos" ${ }^{87}$ Assim, Veigl (2006 [1785], p.231) sintetizava a opinião ilustrada contra a superstição, o charlatanismo e o oportunismo, representados pelos xamãs: "Muchos son los que se arrogan ser hechiceros por mantener sumisos a otros que no lo son $y$ poder apropiarse, por temor de daños mayores, de todo lo que apetecen;

86 MERCADO (1957 [1684], t. 4, p.249). Os xamãs, também na opinião do P. Gumilla, não tinham trato com o demônio, o que buscavam era prestígio. Fingiam-se de amigos do demônio, sem de fato travar conversação alguma com o inimigo comum, antes o faziam por seu próprio interesse, para sobressair, e ser temidos do resto dos índios, para que não se lhes negasse coisa alguma que pedissem, viver respeitados, atendidos, e com abundância de tudo o que necessitassem (GUMILLA, 1955 [1741], p.247-248). Posição semelhante a respeito dos xamãs expressava o P. Magnin: “Estos son pocos los verdaderos; los q' quieren serlo, para grangear estimaciones, son muchos; q' es indecible el respeto, q. les tienen, por el soplo, o con yerbas hechizan, y por el soplo, con canciones, o chupando curar a los enfermos, q' de ordinario son asimismo médicos. Varias drogras tienen para el caso [...] fuera de inumerables otros abusos con sueños, y supersticiones". Usavam de alucinógenos para dar conta de quem havia sido responsável por lançar feitiços (AHN, Jesuitas, leg. 251, n. 2, d. 4, "Breve descripción", Juan Magnin, 1740, f. 18-19).

87 "Noticias exhaustivas" [1785], por Francisco Javier Veigl, MATTHEI; MORENO JERIA, 2001, p.187-188. 
y aunque sólo embaucan a la gente ingenua con charlatanería, sea dicho con el permiso de nuestros graciosos adictos a la nueva filosofía, que no existe nación alguna, por más ruda que sea, que desconozca al el diablo".

Nota-se portanto um desencantamento progressivo do pensamento dos jesuítas a respeito do poder dos xamãs e da capacidade destes de comunicarem-se com o demônio, a ponto de que os escritos do exílio - do qual o texto de Veigl é exemplar - já mostrarem uma atitude cética em relação aos especialistas nativos. Nesse escrito do exílio, o jesuíta preferia não demonizar as práticas indígenas, antes atribuía-lhes o caráter de pueris e simplórias, fruto da ignorância, não da ação do demônio: assim, sobre o que pensavam a respeito da vida após a morte, escreve: "En su simpleza los indios pueden creer que los pájaros o los cuadrúpedos pueden gozar de razón como los humanos, o como enseña Pitágoras, que los espíritus de los difuntos pueden entrar en los cuerpos de los animales por algún tiempo". 88

Aqui é preciso enfatizar uma distinção importante: se alguns jesuítas qualificavam como embustes o que faziam os xamãs, isso não excluía a possibilidade do diabo tirasse proveito desses enganos. O P. Figueroa (1904 [1661], p.236-237), por exemplo, rechaçava a possibilidade de que os índios pudessem contatar o mundo espiritual autonomamente, e desmascarava as trapaças que estavam por trás desses supostos tratos com o diabo. Contudo, não desprezava completamente a figura dos xamãs, pois o demônio podia valer-se deles para promover os seus desígnios. Nessas circunstâncias, as ações dos xamãs podiam ser enquadradas como "superstições”, o que longe de atenuá-las, remetiam à causalidade natural do demônio e à noção de pacto demoníaco implícito (sobre essa noção, ver Clark, 1997, p.480, p.487).

Por outro lado, uma fonte segura de poder dos xamãs residia precisamente em difundir a crença de que eram os únicos capazes de se comunicar com o demônio, o que levava alguns missionários a suspeitarem de

88 "Noticias exhaustivas" [1785], por Francisco Javier Veigl, MATTHEI; MORENO JERIA, 2001, p.187-188. 
que tivessem contraído o pacto demoníaco. ${ }^{89} \mathrm{O}$ missionário dos Cunivo era categórico ao constatar que alguns xamãs mantinham pactos com o inimigo comum: "no hay duda de que algunos tienen pacto con el diablo, que con ruidos, estruendos nocturnos, ahullidos, lloros, gritos, suele darles a entender las desgracias que a sus parientes ausentes suceden". ${ }^{90}$ Dos dois bruxos mais famosos dos Cunivos, um verificou-se ser um embusteiro (uma senhora idosa atrás de uma cortina fazia-se de oráculo); quanto ao outro, julgavam os jesuítas que tivesse pacto com o demônio, por haver revelado, segundo se acreditava, uma morte sucedida à distância de 3 mil léguas, e depois confirmada. ${ }^{91} \mathrm{O}$ autor da arte da língua dos Tucano reconhecia a possibilidade de pacto demoníaco, por meio da ingestão da erva pegí: "floripondio, peghi. Esto es lo que uzan mas los vinia paenistas, ya para adevinar o para pedir algo al Demonio. Çiertamen[te] los antiguos alcansaron pacto con el Demonio, por medio desta mata". ${ }^{2}$

89 Nos séculos XVI e XVII, foi amplamente difundida a crença de que os chamados "especialistas" podiam contrair pactos, segundo o modelo de servidão feudal, com o próprio demônio. Tem-se notícia das pessoas que confessavam, não raro depois de longas sessões de tortura, terem vendido a alma ao demônio, e pelos mais variados motivos: dinheiro, fama, títulos, e mesmo (ironicamente) o prestígio de ser um pastor famoso (THOMAS, 1997, p.474). A noção de pacto diabólico foi uma das poucas que a teologia incorporou da religiosidade popular, mais precisamente da lenda de Teófilo, um clérigo da Ásia Menor que, para obter um posto de bispo que escapara de suas mãos, firmou um pacto com o demônio, com os mesmos protocolos da vassalagem feudal (RUSSELL, 1995, p.155).

90 Comillas/CP, Serie Negra, Cuaderno n. 108, "Letras Anuas de la Misión de la Trinidad de Cunivos", f. 109.

91 Comillas/CP, Serie Negra, Cuaderno n. 108, "Letras Anuas de la Misión de la Trinidad de Cunivos", f. 109-110.

92 NYPL, Obadiah Rich Collection, n. 30. "Arte de lengua”, 4 mai. 1753, f. 38v. Tratos entre o demônio e os xamãs eram atestados pelo P. NICLUTSCH (2012 [1781]. p.124), que alertava: "Sobre todo el misionero debe cuidarse de los impíos brujos, que abundan entre los salvajes y que los cabeliados llaman 'queneque', otros piazes y los españoles brujos". Chama a atenção esse reconhecimento do jesuíta de que os xamãs continuavam em atividade e de que "estos mantienen sin duda amistad y trato clandestino con el Maligno, al que llaman su buen amigo y que suele hablar con ellos, especialmente a través de un papagayo, y les insinúa diversas intrigas y maquinaciones contra los misioneros y su doctrina”. 
Era difícil, contudo, para os jesuítas, desterrar completamente a crença comum no poder dos xamãs porque eles mesmos eram aceitos nas comunidades como xamãs mais poderosos, generosos e efetivos. Sua aceitação estava, portanto, condicionada a que não desencantassem as comunidades a respeito do poder que certas pessoas podiam ter de atuar como mediadores com o mundo sobrenatural e como distribuidores de presentes (Necker, 1979, p.43-52, p.217-229). A autoridade do padre, como a dos chefes, estava baseada na capacidade de fazer circular uma grande quantidade de bens. ${ }^{93} \mathrm{O}$ missionário era recebido como um xamã, ou seja, alguém que possuía a inusual capacidade de manipular forças espirituais. Por essa razão, era visto como um provedor tanto de benefícios como de pragas e maldições. Seus feitiços traziam a morte e a cura (Richter, 1985, p.6). Esperava-se que o jesuíta suprisse a falta dos médicos xamãs a quem substituiu. "Un misionero está obligado a preocuparse también por la salud corporal de sus enfermos y reemplazar si es posible al médico inexistente", refere o P. Zephyris, que se vangloriava de haver lido obras de medicina durante sua estadia na Espanha, então mais úteis do que se tivesse lido outras obras literárias. ${ }^{94}$

Ironicamente, era devido à permanência de certos esquemas de pensamento que os xamãs seguiam sendo influentes nas missões, mas era graças a esses mesmos esquemas (que os jesuítas diziam combater) que os missionários eram aceitos e podiam contar com a adesão das comunidades. Jesuítas e xamãs apresentavam-se como mediadores com o mundo sobrenatural. Em certas ocasiões, os jesuítas não duvidavam de que os xamãs podiam ser veículos de poderes sobrenaturais, que deveriam ser combatidos no mesmo terreno. ${ }^{95} \mathrm{O}$ missionário do rio

93 AGI, Quito, 158, Nicholas Schindler ao tenente-general de Borja, San Joaquín, 5 out. 1737, f. 259v; AGI, Quito, 131, n. 67, "Memoria y razón”, Luis de Iturbide, Borja, 12 jul. 1727, f. 2; AGI, Quito, 328, Manuel Mariano de Echeverría a Serafín Veyan, Quito, 10 fev. 1776, f. 830.

94 Francisco Javier Zephyris a Francisco Javier Goettner, Andoas, 10 jul. 1727, MATTHEI, 1972, p.215.

95 No Chaco, os xamãs eram considerados, pelos jesuítas, como "emisarios de Satanás", como observa VITAR, 2001, p.213: "Una fuerte rivalidad entre hechiceros y sacerdotes se operaba, sobre todo, en el terreno de las curaciones y también en el de los 'milagros', como el 
Pastaza atribuía a grande mortandade de neófitos às bruxarias de "cierto archibrujo [que] había apostatado de la fe". Para remediar a situação, procedeu aos "exorcismos rituales como de la intercesión de los santos Nepomuceno, Ignacio de Loyola, Javier y de Francisco de S. Jerónimo”. O padre não atribuía a outra razão que não à feitiçaria o terem sido atingidos, alguns índios e ele mesmo, por algumas pedras atiradas não se sabe de onde. Também não havia razões para não reconhecer o poder efetivo da água benta na cura de alguns índios enfermos. ${ }^{96}$

Ao qualificar como obra do demônio e não como charlatanismo certas atitudes dos xamãs, os jesuítas expressavam a crença de que se moviam no mesmo terreno que seus rivais, o terreno do sobrenatural. Assim se compreende que os feitiços fizessem parte da tensão cotidiana entre jesuítas e xamãs. Um malfeitor, repreendido pelo missionário por sua obsessão pela magia e pelas superstições, lançara contra o padre uma bolinha - "obtenida por un pacto con el diablo" - capaz de contagiar a quem tocasse com uma febre maléfica. Contudo, segundo o P. Julián, que reuniu essa notícia, "Dios habría protegido a su servidor, desviando la bolita hacia el mismo brujo, quien cayó enfermo de una peste maligna. El infeliz habría confesado su maldad, abjurado de sus concomitancias con el espíritu infernal y concluido por fin su vida con muchas señales de auténtico arrepentimiento y como sería de esperar, en la paz del Señor" ${ }^{97}$

Apesar de tudo, os jesuítas não puderam desterrar completamente as práticas de feitiçaria, nem a crença em seu poder, porque assentavam seu próprio prestígio à sua homologia com a figura dos feiticeiros. Aceitos como novos xamãs, mais generosos, mais eloquentes, dotados de um poder mágico mais efetivo, era-lhes impossível, e mesmo indesejável, destruir a mentalidade que assegurava sua aceitação.

de provocar llegada de lluvias benefactoras o conjurar la acción de las tempestades u otros fenómenos naturales violentos".

96 Francisco Javier Zephyris a Hermenegildo Adam, Andoas, 3 jan. 1728, MATTHEI, 1972, p.236.

97 Juan Bautista Julián a Sebastian Sutor, Laguna, 4 out. 1730, MATTHEI, 1972, p.257. 


\section{CONSIDERAÇõES FINAIS}

Durante o Século das Luzes, a figura do demônio tende a aparecer cada vez menos nos relatos jesuíticos, especialmente entre os escritos do exílio. Assim se compreende uma posição como a do P. Veigl que, em vez de demonizar as práticas indígenas, prefere ridicularizá-las, ao lembrar da "simpleza" dos que acreditavam que os animais gozavam de razão como os humanos. ${ }^{98}$ Estava em curso uma mudança na mentalidade da Europa ocidental desde fins do século XVII. Como assinala Mandrou (1980, p.540), pouco a pouco se impôs entre os magistrados do tribunal de Paris a tese da irresponsabilidade dos feiticeiros, que passavam a ser descritos mais como pessoas ridículas do que como vassalos do demônio. A atitude das elites em relação aos setores populares tornou-se mais paternalista e depreciativa, com o predomínio de opiniões de que se tratava de gente rude, incapaz de perceber a complexidade da fé ou ter um juízo apurado. ${ }^{99}$

Enquanto estiveram na América, contudo, os jesuítas continuaram a insistir na realidade física do demônio, o que motivou este artigo a refletir sobre o papel dessa figura no encontro missionário e cultural havido nas terras baixas amazônicas. Cumpre enfatizar que a demonização não se reduzia a uma mera desqualificação da alteridade, pois se o Outro também podia ser tentado pelo inimigo comum, era porque

98 "Noticias exhaustivas" [1785], por Francisco Javier Veigl, MATTHEI; MORENO JERIA, 2001, p.187-188.

99 Para esse processo no império português, que culminou no Regimento do Santo Ofício de 1774 - o qual manifestava uma atitude mais racionalista, ao afirmar que os feitiços não podiam ser dotados de poderes mágicos advindos do pacto demoníaco, e que eram incapazes de "romper as leis fundamentais da ordem da natureza" -, ver MELLO E SOUZA, 1986, p.325 e SOUZA, 2012, p.49. Também os inquisidores da Nova Espanha passaram a demonstrar uma postura moderna e cética, influenciada por novos paradigmas científicos, e a dar por falsas as declarações de possessão demoníaca (CERVANTES, 1996, p.194-196). Na Inglaterra, a emergência da filosofia mecânica concebia um universo ordenado, regido por leis da física e imune à intervenção de Deus ou do Diabo. THOMAS, 1997, p.582, mostra como, mesmo antes do Witchcraft Act de 1736, já se tornara difícil trazer um novo processo de bruxaria aos tribunais, e desvela a importância das Poor Laws para o esvaziamento da perseguição formal. 
se mantinha aberta a possibilidade do diálogo intercultural (García Gavidia, 1995, p.218 s.s).

Este texto analisou os discursos dos missionários europeus, e em especial dos jesuítas, que inseriam o processo de "conquista espiritual" em uma narrativa de luta entre as forças do bem e do mal. Os jesuítas apresentavam-se como aqueles que vieram libertar os índios que viviam acorrentados à adoração do demônio, que se servia dos xamãs para promover toda a sorte de conflitos e danos. Os missionários empregavam a figura do diabo para explicar aqueles traços rituais ou míticos mais contrastantes e opacos em relação ao catolicismo; ironicamente, também viam o demônio naqueles elementos religiosos mais parecidos ou equiparáveis ao culto católico, celebrações e sacramentos que "imitavam" os da religião cristã. Nesse sentido, o demônio era o mais oposto e o mais parecido a Deus. A imagem do demônio permitia a tradução de uma cultura em outra, de modo a tornar inteligíveis as práticas e concepções mais perturbadoras (Pino Díaz, 2002, p.152; Agnolin, 2009, p.229-230).

A demonização permitia recriminar aqueles aspectos vistos como incompatíveis com o cristianismo, mas não se esgotava aí. Atribuir ao demônio a responsabilidade pelos conflitos e revoltas que sucediam nas missões equiparava os índios aos europeus no sentido de que ambos eram igualmente sujeitos à tentação e à influência do maligno, o que mantinha aberta a possibilidade de uma construção negociada de um terreno de mediação cultural em que as alteridades podiam traduzir-se. A imagem do demônio, sem deixar de ser instrumento de classificação e dominação, conduzia a uma inevitável imersão no mundo da cultura nativa.

\section{Agradecimentos}

Fundação de Amparo à Pesquisa do Estado de São Paulo (Fapesp); Fundación Slicher Van Bath de Jong (Centre for Latin American Research and Documentation, Holanda) 


\section{REFERÊNCIAS BIBLIOGRÁFICAS}

AGNOLIN, Adone. O governo missionário das almas indígenas: missão jesuítica e ritualidade indígena (séc. XVI-XVII). In: MELLO E SOUZA, Laura de et al. (orgs.). O governo dos povos. São Paulo: Alameda, 2009. p.213-239.

ARENZ, Karl Heinz. Além das doutrinas e rotinas: índios e missionários nos aldeamentos jesuíticos da Amazônia portuguesa (séculos XVII e XVIII). Revista História e Cultura, vol. 3, n. 2, p.63-88, 2014.

BAUDOT, Georges. Diablos, demonios y sortilegios. In: BAUDOT, Georges. México y los albores del discurso colonial. México: Nueva Imagen, 1996. p.225-241.

BAYLE, Constantino, S.J. Notas sobre bibliografía jesuítica de Mainas. Madrid: Jura, 1949.

BERNABÉU ALBERT, Salvador. El diablo en California. Recepción y decadencia del maligno en el discurso misional jesuita. In: BERNABÉU ALBERT, Salvador (ed.). El Septentrión Novohispano: ecohistoria, sociedades e imágenes de frontera. Madrid: CSIC, 2000. p.139-176.

BERNAND, Carmen; GRUZINSKI, Serge. De la idolatría: una arqueología de las ciencias religiosas. México: Fondo de Cultura Económica, 1992.

CAÑIZARES-ESGUERRA, Jorge. Católicos y puritanos en la colonización de América. Madrid: Marcial Pons, 2008.

CERTEAU, Michel de. Travel Narratives of the French to Brazil: Sixteenth to Eighteenth Centuries. In: GREENBLATT, Stephen (ed.). New world encounters. Berkeley: Univ. of California Press, 1993. p.323-328.

CERVANTES, Fernando. Christianity and the Indians in Early Modern Mexico: the Native Response to the Devil. Historical Research, vol. 66, n. 160, p.177-196, 1993.

CERVANTES, Fernando. El diablo en el Nuevo Mundo: el impacto del diabolismo a través de la colonización de Hispanoamérica. Barcelona: Herder, 1996.

CIPOLLETTI, María Susana. Aipë koka: la palabra de los antiguos, tradición oral Siona-Secoya. Quito: Abya-Yala, 1988. 
CLARK, Stuart. Thinking with demons: the idea of witchcraft in early modern Europe. Oxford: Clarendon Press New York, 1997.

DELUMEAU, Jean. El miedo en Occidente (siglos XIV-XVIII): una ciudad sitiada. Madrid: Taurus, 2012.

DOCTRINA christiana y catecismo para instrucción de Indios, vol. 2. Madrid: CSIC, 1985.

DUVERGER, Christian. La conversión de los indios de Nueva España: con el texto de los Coloquios de los Doce de Bernardino de Sahagún (1564). México: Fondo de Cultura Económica, 1993.

DUVIOLS, Pierre. La destrucción de las religiones andinas: conquista y colonia. México: Univ. Nacional Autónoma de México, 1977.

ESTENSSORO FUCHS, Juan Carlos. Del paganismo a la santidad: la incorporación de los indios del Perú al Catolicismo (1532-1750). Lima: IFEA, 2003.

FLORES ARROYUELO, Francisco José. El diablo en España. Madrid: Alianza, 1985.

GARCÍA GAVIDIA, Nelly. Los indígenas venezolanos: de su demonización en la 'Historia de la nueva Andalucía' (1779) a la persecución actual por la ideología del progreso. In: PINO DÍAZ, Fermín del; LÁZARO, Carlos (eds.). Visión de los otros y visión de sí mismos: ¿descubrimiento o invención entre el Nuevo Mundo y el Viejo? Madrid: CSIC, 1995, p.205-232.

GAREIS, Iris. Como el diablo llegó a los Andes: introducción y trayectoria de un concepto europeo en el Perú colonial. In: GAREIS, Iris (ed.). Entidades maléficas y conceptos del mal en las religiones latinoamericanas. Aachen: Shaker Verlag, 2008. p.41-69.

GOLOB, Ann. The Upper Amazon in historical perspective. Thesis (Ph.D.) - City Univ. of New York. New York, 1982.

GREEN JR., Robert L. Masters of Idolatry: Catholic Colonialism, Jesuit Conversionary Thought, and Indigenous Religious Traditions in the Spanish Pacific World, 1568-1672. Dissertation (Ph.D.) - Univ. of California. Santa Barbara, 2011.

GROHS, Waltraud. Los indios del Alto Amazonas del siglo XVI al siglo XVIII: poblaciones y migraciones en la antigua provincia de Maynas. Bonn: Udo Oberem, 1974. 
GRUZINSKI, Serge. O pensamento mestiço. São Paulo: Companhia das Letras, 2001.

JOUANEN, José, S.J. Historia de la Compañía de Jesús en la antigua provincia de Quito: 1570-1773, 2 vols. Quito: Ecuatoriana, 1941-1943.

MACCORMACK, Sabine. Demons, Imagination, and the Incas. Representations, n. 33, p.121-146, 1991a.

MACCORMACK, Sabine. Religion in the Andes: vision and imagination in early colonial Peru. Princeton, N.J.: Princeton Univ. Press, 1991b.

MANDROU, Robert. Magistrats et sorciers en France au XVII siècle: une analyse de phychologie historique. Paris: Seuil, 1980.

MARTINI, Mónica Patricia. Imagen del diablo en las reducciones guaraníes. Investigaciones y Ensayos, n. 40, p.335-360, 1990.

MATTHEI, Mauro (ed.). Cartas e informes de misioneros jesuitas extranjeros en Hispanoamérica, vol. 1. Santiago, Chile: Pontificia Univ. Católica, 1969.

MATTHEI, Mauro (ed.). Cartas e informes de misioneros jesuitas extranjeros en Hispanoamérica, vol. 2. Santiago, Chile: Pontificia Univ. Católica, 1970.

MATTHEI, Mauro (ed.). Cartas e informes de misioneros jesuitas extranjeros en Hispanoamérica, vol. 3. Santiago, Chile: Pontificia Univ. Católica, 1972.

MATTHEI, Mauro; MORENO JERIA, Rodrigo (eds.). Cartas e informes de misioneros jesuitas extranjeros en Hispanoamérica, vol. 4. Santiago, Chile: Pontificia Univ. Católica, 1997.

MATTHEI, Mauro; MORENO JERIA, Rodrigo (eds.). Cartas e informes de misioneros jesuitas extranjeros en Hispanoamérica, vol. 5. Santiago, Chile: Pontificia Univ. Católica, 2001.

MELLO E SOUZA, Laura de. Inferno atlântico: demonologia e colonização, séculos XVI-XVIII. São Paulo: Companhia das Letras, 1993.

MELLO E SOUZA, Laura de. O diabo e a Terra de Santa Cruz: feitiçaria e religiosidade popular no Brasil colonial. São Paulo: Companhia das Letras, 1986.

MILLS, Kenneth. Idolatry and its enemies: colonial Andean religion and extirpation, 1640-1750. Princeton, N.J.: Princeton Univ. Press, 1997. 
NECKER, Louis. Indiens Guarani et chamanes franciscains: les premières réductions du Paraguay 1580-1800. Paris: Anthropos, 1979.

NICOLETTI, María Andrea. La evangelización en las misiones norpatagónicas coloniales: ¿convertir o salvar?. Jahrbuch für Geschichte Lateinamerikas, n. 36, p.125-150, 1999.

PAGDEN, Anthony. La caída del hombre: el indio americano y los orígenes de la etnología comparativa. Madrid: Alianza, 1988.

PARDO, Osvaldo F. The origins of Mexican Catholicism: Nahua rituals and Christian sacraments in sixteenth-century Mexico. Ann Arbor: Univ. of Michigan Press, 2004.

PHELAN, John Leddy. El reino milenario de los franciscanos en el Nuevo Mundo. México: Univ. Nacional Autónoma de México, 1972.

PIÑAS RUBIO, Francisco, S.J. Cartas Annuas de la Compañía de Jesús en la Audiencia de Quito de 1587 a 1660. Alicante: Biblioteca Virtual Miguel de Cervantes, 2008.

PINO DÍAZ, Fermín del. Inquisidores, misioneros y demonios americanos. In: PINO DÍAZ, Fermín del (ed.). Religión y Sociedad entre España y América. Madrid: CSIC, 2002. p.139-160.

RAGON, Pierre. 'Démonolâtrie' et démonologie dans les recherches sur la civilisation mexicaine au XVIe siècle. Revue d'histoire moderne et contemporaine, t. 35, n. 2, p.163-181, 1988.

REDDEN, Andrew. Diabolism in colonial Peru, 1560-1750. London: Pickering \& Chatto, 2008.

REEVE, Mary-Elizabeth. Regional Interaction in the Western Amazon: The Early Colonial Encounter and the Jesuit Years: 1538-1767. Ethnohistory, vol. 41, n. 1, p.106-138, 1993.

REFF, Daniel T. La representación de la cultura indígena en el discurso jesuita del siglo XVII. In: LA COMPAÑÍA de Jesús en América: evangelización y justicia: siglos XVII y XVIII: actas del Congreso Internacional de Historia, Córdoba, España, 1991. Córdoba: Provincia de Andalucía y Canarias de la Compañía de Jesús, 1993. p.307-314.

REY FAJARDO, José del, S.J. Documentos jesuíticos relativos a la historia de la Compañía de Jesús en Venezuela, 3 vols. Caracas: Academia Nacional de la Historia, 1966-1974. 
RICARD, Robert. La conquista espiritual de México: ensayo sobre el apostolado y los métodos misioneros de las órdenes mendicantes en la Nueva España de 1523-1524 a 1572. México: Fondo de Cultura Económica, 1986.

RICHTER, Daniel K. Iroquois versus Iroquois: Jesuit Missions and Christianity in Village Politics, 1642-1686. Ethnohistory, vol. 32, n. 1, p.1-16, 1985.

RÍPODAS ARDANAZ, Daisy. Pervivencia de hechiceros en las misiones guaraníes. Folia histórica del Nordeste, n. 6, p.199-217, 1984.

ROZAT DUPEYRON, Guy. América, imperio del demonio: cuentos y recuentos. México, DF: Univ. Iberoamericana, Departamento de Historia, 1995.

RUSSELL, Jeffrey Burton. El príncipe de las tinieblas: el poder del mal y del bien en la historia. Santiago de Chile: Andres Bello, 1995.

SEED, Patricia. Ceremonies of possession in Europe's conquest of the New World, 1492-1640. Cambridge, UK; New York: Cambridge Univ. Press, 1995.

SILVERBLATT, Irene. Dioses y diablos: idolatrías y evangelización. Allpanchis, vol. 16, n. 19, p.31-47, 1982.

SILVERBLATT, Irene. Luna, sol y brujas: géneros y clases en los Andes prehispánicos y coloniales. Cusco: Centro de Estudios Andinos "Bartolomé de las Casas", 1990.

SOUZA, George Evergton Sales. Catolicismo ilustrado e feitiçaria. Resultados e paradoxos na senda da libertação das consciências. CEM Cultura, Espaço \& Memória, vol. 3, p.45-62, 2012.

STEPHAN, Jörg. Spanische Herrschaft und Mission in der Grenzprovinz Maynas: 1619-1768. Stuttgart: Heinz, 2000.

THOMAS, Keith. Religion and the decline of magic: studies in popular beliefs in sixteenth and seventeenth century England. New York: Oxford Univ. Press, 1997.

TORRES-LONDOÑO, Fernando. Contato, guerra e negociação: redução e cristianização de Maynas e Jeberos pelos jesuítas na Amazônia no século XVII. História Unisinos, vol. 11, n. 2, p.192-202, 2007.

VITAR, Beatriz. La evangelización del Chaco y el combate jesuítico contra el demonio. Andes, vol. 12, p.201-222, 2001.

WILDE, Guillermo. Adaptaciones y apropiaciones en una cultura textual de frontera: impresos misionales del Paraguay Jesuítico. História Unisinos, vol. 18, n. 2, p.270-286, 2014. 